\title{
Review Article \\ Recent Nanotechnology Approaches for Prevention and Treatment of Biofilm-Associated Infections on Medical Devices
}

\author{
Mohankandhasamy Ramasamy and Jintae Lee \\ School of Chemical Engineering, Yeungnam University, Gyeongsan 38541, Republic of Korea \\ Correspondence should be addressed to Jintae Lee; jtlee@ynu.ac.kr
}

Received 5 July 2016; Accepted 13 October 2016

Academic Editor: Ariel Kushmaro

Copyright (C) 2016 M. Ramasamy and J. Lee. This is an open access article distributed under the Creative Commons Attribution License, which permits unrestricted use, distribution, and reproduction in any medium, provided the original work is properly cited.

\begin{abstract}
Bacterial colonization in the form of biofilms on surfaces causes persistent infections and is an issue of considerable concern to healthcare providers. There is an urgent need for novel antimicrobial or antibiofilm surfaces and biomedical devices that provide protection against biofilm formation and planktonic pathogens, including antibiotic resistant strains. In this context, recent developments in the material science and engineering fields and steady progress in the nanotechnology field have created opportunities to design new biomaterials and surfaces with anti-infective, antifouling, bactericidal, and antibiofilm properties. Here we review a number of the recently developed nanotechnology-based biomaterials and explain underlying strategies used to make antibiofilm surfaces.
\end{abstract}

\section{Introduction}

Biofilms are organized colonies of bacteria, fungi, or yeasts that form heterogeneous entities on biotic or abiotic surfaces by secreting extracellular polymeric substances (EPS). These substances protect individual cells from hostile factors, such as immunologic defense systems, nutrient limitations, and antibacterial agents [1]. The genotypic and phenotypic characteristics of cells in biofilms differ from those of their free-floating counterparts, and these differences make them strongly resistant to antibiotics. This resistance has been attributed to the failure of antibiotics to penetrate biofilms, the induction of multidrug efflux pumps of biofilm-specific phenotypes, and the presence of persisters $[2,3]$. Basically, microbes have the ability to adhere to surfaces, including those of inert materials, synthetic polymers, and indwelling medical devices, and this leads to colonization and mature biofilm development. Furthermore, cell detachment from mature biofilms leads to infection dissemination and transmission [4, 5]. In fact, clinical infections caused by biofilms are a more challenging healthcare issue than those caused by planktonic cells, and microbial infections caused by bacterial biofilms on biomedical surfaces are a leading cause of death worldwide $[6,7]$. As a result, there is an urgent clinical need to develop long-lasting biomedical materials or devices with antibacterial and antibiofilm surfaces.

Nanometer scale materials have been adopted for many biomedical applications due to the greater reactivities conferred by their large surface to volume ratios and ability to control their physicochemical properties. In fact, applications of nanotechnology in medicine resulted in a new field called "nanomedicine" which has already provided novel treatments against a wide range of diseases. Nanomaterial development is now viewed as a promise strategy for controlling or treating pathogenic biofilms on indwelling medical devices and implants. Most of the nanoparticles examined have been metals (e.g., copper, silver, iron, zinc, titanium, magnesium, or gold), metal oxides, polymers (e.g., nanoporous polymers), metal-based polymeric composites, peptides, or combinations of these, or liposomes, antibiotic encapsulated nanoparticles, or responsive smart nanomaterials that have antimicrobial effects but cause minimal damage to the host. Drug loaded nanoparticles could overcome the limitations of conventional antibiotic treatments associated with toxicity, improper delivery, or enzymatic degradation. In addition, hydroxyapatite, chitosan, collagen, silica, and titanium dioxide have been used as nanomatrices to incorporate antimicrobials because of their bioactivities, 


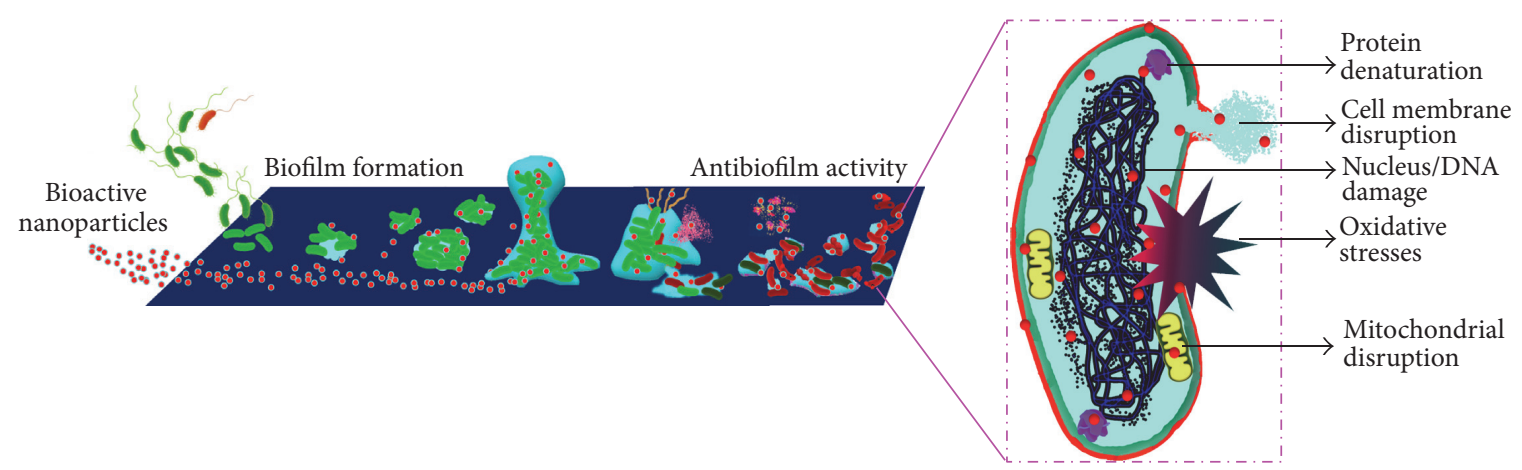

FIGURE 1: Schematic illustration of biofilm development and mechanisms responsible for the antimicrobial and antibiofilm effects of nanoparticles.

biocompatibilities, low toxicities, and noninflammatory and nonimmunogenic characteristics $[8,9]$. Recently, novel physical approaches like near-infra red light (NIR) or alternating magnetic fields (AMFs) have been utilized with nanoparticles to cause irreversible thermal damage to cell surfaces and bacterial biofilm eradication [10, 11]. These promising developments could possibly be adapted to treat wound biofilm infections in a noninvasive, on-demand manner.

This review highlights current strategies of nanotechnology-based approaches designed to control or eradicate biofilm related infections with special emphasis on nanoparticle embedded biomedical materials.

\section{Bacterial Biofilms: Formation to Dissemination}

It is now realized that most bacterially derived sessile communities are capable of forming irreversible biofilms on surfaces and interfaces by embedding themselves deep in a selfgenerated polymeric matrix [43]. Furthermore, most of the fungal species that form biofilms do so in a similar manner; Candida and Aspergillus are fungal species of particular interest [44]. The mechanism of biofilm formation depends on environmental stimuli and a series of genetic and phenotypic changes in planktonic cells. To date, five different stages [45] have been suggested during biofilm development (Figure 1), namely, (i) reversible-irreversible adherence, (ii) microcolony formation, (iii) 3D biofilm formation, (iv) maturation, and (v) dissemination [46]. In the earliest stage, biofilm development involves surface preconditioning and the adsorption of macromolecules, followed within seconds of surface exposure, by the formation of a conditioning layer. During the second stage, microorganism adhesion and coadhesion are strengthened by strong chemical attachments to the matrix polymer, and the unfolding of cell surface structures results in the exudation of a polysaccharide slime that attracts cells and debris. During the third stage, the nutrient rich biofilm environment promotes rapid microorganism growth that ultimately results in biofilm development in a 3D manner that substantially increases biofilm thickness. As film thickness increases, the forth maturation stage is reached, which is associated with antibiotic resistance. In the final stage, due to dynamic flux of the biofilm matrix, microorganisms detach, either actively or passively, and enter the surrounding environment as planktonic cells on a regular basis. Detached cells can also disseminate to fresh surfaces in the forms of detached biofilm clumps or fluid-driven cell clusters. Furthermore, bacteria originating from biofilm communities colonize new areas to produce new sessile populations.

\section{Biofilm Formation and Biofouling}

Biofouling (Figure 1) is defined as the accumulation of unwanted proteins and other analytes or microorganisms on the surfaces of host materials. Microbial contamination and associated infections can have serious consequences in a number of environments, including hospitals and the food industry and in community-related settings [47]. Fouling caused by marine organisms is also an issue of concern for industry and boating. After attaching to a surface, biofouling organisms can form a conditioning layer that provides an active platform for diatoms and algae, which results in increased operational and maintenance costs and the accelerated degradation of abiotic materials. Likewise, membrane fouling hampers pressure-driven membrane processes, such as reverse osmosis, microfiltration, ultrafiltration, and nanofiltration, used for water treatment and desalinization. Membrane biofouling is caused by Aeromonas, Arthrobacter, Bacillus, Corynebacterium, Flavobacterium, and Pseudomonas sp. and to a lesser extent by other microorganisms, like, fungi [48].

In vivo, nonspecific protein adsorption facilitates bacterial attachment to surfaces and leads to colonization, subsequent biofilm formation (Figure 1), and infectious disease. Protein fouling followed by microbial attachment with biofilm development is a dormant factor of the failure of biomedical devices and implants. Furthermore, microbial attachment reduces the sensitivities and efficacies of devices, including those of in vitro diagnostic equipment, such as those required for immunological assays, and thus has therapeutic impacts [49].

Biofilms infections of teeth, lungs, skin, heart, and the urinary tract are always detrimental [50, 51]. Wounds and implants are susceptible to Staphylococcus aureus and 
Staphylococcus epidermidis infections [52, 53]. Staphylococcus is responsible for most hospital acquired pneumonia cases and Pseudomonas aeruginosa also forms biofilms in lungs [54, 55]. In addition, multidrug resistant Gram-negative bacterial species, such as, Escherichia coli, Klebsiella pneumoniae, and $P$. aeruginosa, causes widespread biofilm-based infections in acute care facilities in hospitals [56, 57]. Dental plaques are tooth biofilms that lead to dental cavities and gum inflammation and infect dental implants.

Nosocomial infections are contracted in medical environments or after direct contact with healthcare settings [59]. Contact with contaminated surfaces or infection by air-borne bacteria or fungal spores places surgical patients at risk [60, 61]. In fact, more than $60 \%$ of hospital related complications and up to $80 \%$ of infection associated deaths are attributable to biofilm infections [62, 63], and nearly $80 \%$ of known pathogenic bacteria have been implicated in device-related infections $[64,65]$, such as intravenous and urinary catheters [66], joint prostheses [67, 68], penile prostheses [69], contact lenses [70], fracture fixation devices [71, 72], breast implants [73, 74], pacemakers [75], endoscopes [76], cardiovascular and biliary stents [77], and coherent implants [78, 79]. Biofilms on these devices transmit bacteria and act as source of infection. Currently, removal of the affected device offers the only permanent means of eradicating infection [80]. Below list describes the device-related biofilm infections.

\subsection{Catheter Biofilm Infections}

3.1.1. Central Venous Catheters. Hematogenous spread of infections from colonized central intravenous catheters or central lines is a long-recognized problem with infection rates of 2 and 6.8 per 1000 days, respectively [81, 82]. Vascular catheters placed for more than 30 days evidenced luminal colonization and biofilm formation which is predominant compared to central venous catheters. Therefore, bone marrow transplant patients that require a long term vascular catheter for intravenous access are at greater risk of biofilm infections $[83,84]$. In clinical practice, vascular catheters are replaced regularly to reduce infection risk, but this practice substantially increases healthcare costs.

3.1.2. Urinary Catheters. Urinary catheterization is routinely used to collect urine during surgery, measure urine output, and prevent urine retention in intensive care unit patients. Periurethral skin colonization is a cause of bacterial contamination as it can result in bladder migration and the establishment of biofilms on catheters [85]. Urease producing bacteria, such as, Proteus, Psuedomonas, and Klebsiella, increase urinary $\mathrm{pH}$ by creating an alkaline environment, which promotes the formation of struvite biofilms within catheters [45]. These crystalline biofilms can form deposits on the outer surfaces, tips, and balloons of catheters and led to severe complications, such as injury to the urinary bladder. Furthermore, biofilm debris may be shed after deflating a catheter balloon, which can block urine flow [86]. The main strategies used to prevent urinary catheter-associated infections are to use catheters only when necessary, to avoid long term catheterization, and to replace catheters regularly. However, frequent replacement and the disruption caused can lead to severe complications, in particular, the spread of bacteria to uncontaminated sites due to biofilm shedding [87-89].

3.2. Endotracheal Tubes. Numerous microorganisms have been reported to colonize and form biofilms in endotracheal tubes. These organisms include methicillin-resistant $S$. aureus (MRSA) and Gram-negative bacilli, such as E. coli, $K$. pneumoniae, $P$. aeruginosa and Acinetobacter spp., which are key factors of ventilator-associated pneumonia development [90]. Reports indicate diverse microorganisms, from orally associated microflora to clinically specific isolates, can form biofilms in endotracheal tubes [91, 92].

3.3. Prosthetic Joints. Increasing evidence indicates underlying biofilm infections are a primary cause of aseptic loosening of joint prostheses. Device-associated infections in prosthetic joints by S. epidermidis or Propionibacterium acnes can induce severe complications and significant mortality after joint replacement surgery $[93,94]$.

3.4. Pacemakers and Heart Valves. In the US, more than 100,000 cardiovascular devices are implanted annually and heart valve infections account for $30 \%$ of implant associated mortalities. S. aureus, S. epidermidis, P. aeruginosa, Acinetobacter baumannii, Klebsiella pneumonia, E. coli, and $P$. acnes are reportedly the most common causative agents of cardiac implant infections [75] on pacemakers, prosthetic valves, defibrillators, and coronary artery bypass grafts, which incidentally grow thicker biofilms in vivo than in vitro [75, 78, 95]. Other microbes, such as Enterococcus and yeasts, also form biofilms on cardiovascular devices [96]. Heart valves have been reported to be targeted by Mycobacterium fortuitum, which causes systemic biofilm infection without causing vegetation. Heart valve biofilms reduce blood flow, cause hematogenous spread, and infect and cause emboli development in other organs. Basically, heart valves are infected by clot formation after injury, because blood clots afford an ideal surface for bacterial adhesion [97].

3.5. Contact Lenses. Although different types of polymeric contact lens materials have been developed in the attempt to prevent biofilm formation, these efforts have been uniformly unsuccessful. Biofilms of certain species, including Candida, $P$. aeruginosa, and Fusarium, are resistant to the biocides in standard contact lens solutions but are susceptible to hydrogen peroxide [98]. However, contact lenses made from hydrogels that release ceragenin are reportedly capable of resisting colonization by $P$. aeruginosa and $S$. aureus for two and four weeks, respectively [99].

3.6. Orthopedic Implants. Up to $15 \%$ of infection-associated hip implant failures required for implant replacement revision surgery are due to bacterial biofilm formation [100], which causes inflammation and tissue destruction around 
implants much more rapidly than the damage caused by gingivitis [101]. Nevertheless, altering implant surface textures by sintering [102], sand blasting [103], or plasma spraying [104] can improve the biofilm resistance of orthopedic implants.

3.7. Breast Implants. Burkhardt et al. proposed that subclinical infections caused capsular contractions around breast implants [105]. Numerous bacteria in breast ducts and tissue result in biofilm formation on breast implants, which had been shown to be the leading cause of contracture [106108]. One study showed S. epidermis adhered and produced biofilms on the breast implant surfaces regardless of surface textures [73].

\section{Approaches to Biofilm Control}

Biological response to a biomedical device depends on the structure and surface functionality of the material used, and most device-associated infections are likely to originate from material surface contamination at time of implantation. Thus, the compositions or surface functionalizations of biomaterials are tailored to achieve desired results. Surface engineering of materials can enhance device biocompatibility and functionality and material properties and surfaces can be modified to reduce microbial contamination and prevent biofilm infections. The different methodologies used include

(1) antifouling coatings [47],

(2) antiadhesive surface modifications [109],

(3) addition of antimicrobials to the surfaces of medical devices [110-112],

(4) coating devices with polymer products [113],

(5) surface engineering with chemical moieties [57, 114116],

(6) coating, lamination, adsorption, or immobilization of biomolecules [117-119].

Microbial attachment to a surface is usually initiated by the formation of an adsorbed protein layer. Immobilizing poly(ethylene glycol) (PEG) or oligo(ethylene glycol) or a zwitterionic species on surfaces is commonly used to produce antifouling surfaces [120-122]. The introduction of sulfonate units, presence of longer brushes, and high molecular weight of poly ethylene molecules strongly resisted E. coli, S. epidermidis, P. aeruginosa, Candida tropicalis, and $C$. albicans attachment [123, 124]. Bacterial adhesion to surfaces is a complex process that is not completely understood, but it appears to be governed by the physical characteristics of bacteria and surfaces, such as surface roughness, hydrophobicity, and charge. Lotus leaves and shark skins have exceptional antifouling properties as their unique microtopographic features make these surfaces super hydrophobic and self-cleaning [125], and many researchers have mimicked this technique $[126,127]$. For example, 95\% bacterial resistance was recorded for a particle-layered polythiophene films by altered surface wettability [128]. A photolithography technique to create the topography of shark skin on polydimethysiloxane (PDMS) resulted in the composite significantly inhibited biofilm colonization by $S$. aureus. Furthermore, different microtopographic structures on PDMS showed $86 \%$ resistance to colonization by the sea weed Ulva $[129,130]$. The inclusion of natural bioactive agents, including antimicrobials, into polymers has been widely applied and utilized in the textile and food industries, for drug delivery and for treating the surfaces of surgical implants and biomedical devices. Natural antimicrobials have also been incorporated into paper [131], thermoset plastics, and thermoplastics [132] and tested against pathogenic E. coli, Listeria monocytogenes, and spoilage organisms, including molds [133]. Additionally, coating glass slides with poly(4vinyl-N-alkylpyridinium bromide) was found to kill airborne bacteria [134].

Antibiotic coatings efficiently provide surface antimicrobial activity because bacteria directly bind with antibiotics and are lysed before biofilm establishment. This strategy has been applied to bone cements [135] used in orthopedic and orthodontic applications $[136,137]$. The surface active biomolecules examined include lactoferrin [138], biosurfactants [139], bacterial adhesion inhibitors [140], antibodyreleasing surfaces [141], nonpathogenic bacteria [142], and quorum sensing (QS) inhibitors [143], and all have been utilized to inhibit and eradicate pathogenic bacterial biofilm development on different biomedical surfaces [144].

Quaternary ammonium compound on different surfaces was disruptive to bacterial colonization and biofilm formation $[134,145]$. However, high concentrations of quaternary ammonium compounds and their cationic natures are harmful to human cells [146, 147], and thus, additional development is needed to make these materials safer; for example, embedding a cationic compound in a peptide containing MAXI hydrogel provided broad antibacterial activity without harming red blood cells or fibroblasts [148]. Accordingly, designs incorporating combinations of suitable materials that do not harm the host environment provide a key to the successful application of antibiofilm coatings [149].

Although antiadhesive coatings may provide benefits for single functionality devices like urinary catheters, voice prostheses, and contact lenses, they are not sufficient for permanent indwelling devices like heart valves, surgical meshes, hip and knee prostheses, or vascular grafts. Effective implant materials must have multifunctional surfaces that provide extended antimicrobial activity and tissue integration and disinfect surrounding tissues after implant revision surgery, but on the other hand they must not alter host immune responses to microorganisms [150]. Current research is focused on more sophisticated surface modification methods to prevent microbial adherence, inhibit microbial growth, and disrupt biofilm formation.

\section{Nanotechnology Based Strategies for Biofilm Control and Treatment}

It is believed nanotechnology-based approaches will provide promising advancements to prevent drug-resistant biofilm infections of medical devices and biomaterials. A small 


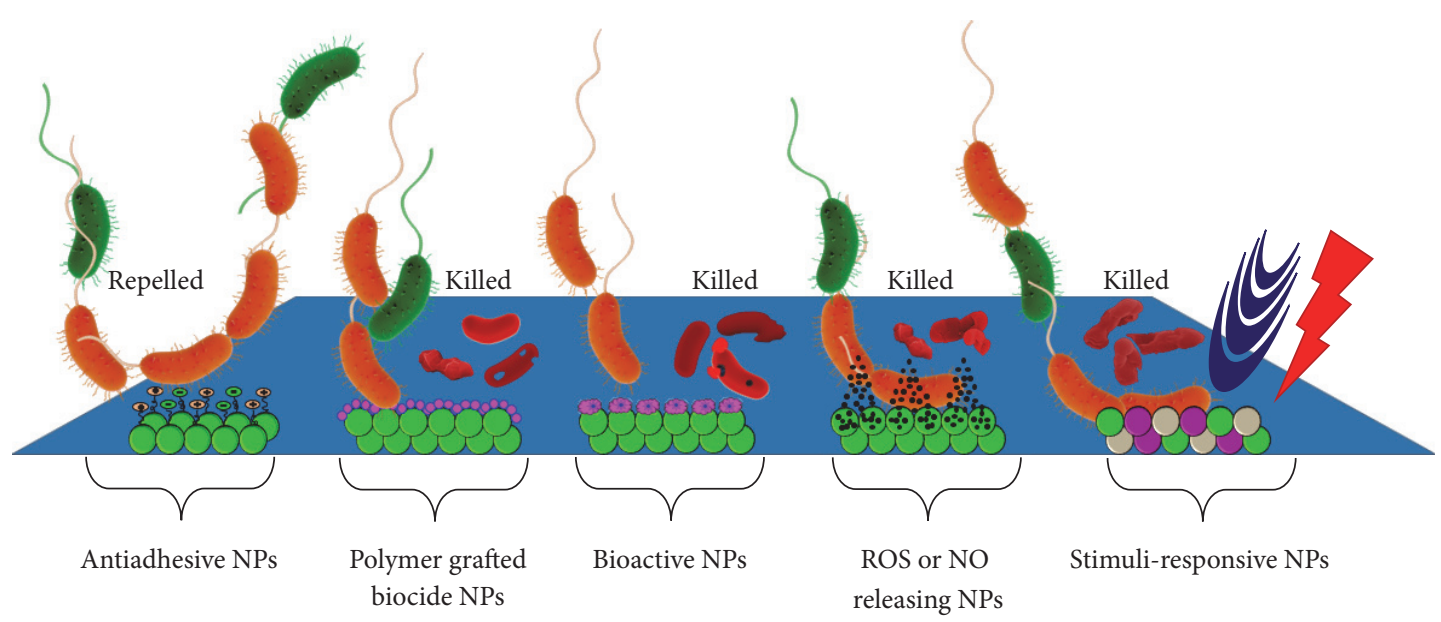

FIGURE 2: Schematic of biofilm inhibition showing the effects of surface-engineered nanomaterials with diverse antimicrobial properties.

number of studies have reported the use of nanoparticle (NP) coated surfaces as biofilm inhibiting agents [151]. At the nanometer scale materials exhibit unique physicochemical and biological properties and sometimes phenomena, such as quantum effects, not exhibited by their bulk counterparts. Nanomaterials have much greater surface area to volume ratios, which enhances chemical reactivities and bioactivities, and their sizes are of the same order as biomolecules. Furthermore, NPs are small enough to penetrate microbial cell walls and even biofilm layers that can cause irreversible damage to cell membranes and DNA. In addition, they have long plasma half-lives and their high surface to volume ratios facilitate the loading of drugs and targeting entities [152].

5.1. Nanoparticles in Antibiofilm Therapy. Recent advances in nanotechnology have identified new and promising opportunities for effective biofilm control and treatment. Summary of different surface-engineered NPs including metal NPs, polymer NPs, metal-polymer composites, biologically active NPs, ROS or NO releasing NPs, and stimuli-responsive smart NPs that are considered to offer the possibility of either preventing or controlling biofilm related infections on medical devices with their respective mechanisms of actions is illustrated in Figure 2.

5.2. Antibacterial Metals. Copper, gold, silver, titanium, and zinc are known to have antibacterial and antibiofilm properties, which offer alternatives to antibiotics without significantly increasing the risk of resistance development. It has been established that metal-based NPs have much better antimicrobial activities than their micro-sized counterparts $[153,154]$. The surface textures of metal coated biomaterials are dependent on coating technique, for example, sintering, plasma spraying, sand blasting, anodization, or electron beam evaporation. Furthermore, devices produced using these techniques exhibit quite different bacterial adhesions, protein adsorptions, and tissue integration characteristics [155-157].
5.2.1. Inorganic Nanoparticles. Several inorganic metal NPs, such as, gold, copper, silver, zinc, and titanium NPs, exhibit antibiofilm activity. Silver nanomaterials have received considerable attraction because of their superior antimicrobial activities. Silver in ionic or NP form has an oligodynamic effect with broad spectrum antibacterial activity and is especially effective against microbial colonizations associated with biomedical infections. The antibacterial mechanism of silver NPs (Ag NPs) is probably due to interactions between silver ions with bacterial wall sulfhydryl groups that interfere with and disrupt bacterial cell membranes [158], enzyme activities [159], respiratory chains [160], and cell proliferation [161]. Ag NPs have also been shown to disrupt biofilm matrices by perturbing intermolecular forces. In one study, $24 \mathrm{~h}$ of treatment with Ag NPs inhibited biofilm formation by $P$. aeruginosa and $S$. epidermidis by more than $95 \%$ and biofilm formation by clinically isolated strains of MRSA and methicillin-resistant S. epidermidis (MRSE) [162]. Silver impregnated hydroxyapatite and silver-titania matrices reduced bacterial adhesion and prevented biofilm generation by Gram-positive and Gram-negative bacteria (Table 1), and the $\mathrm{TiO}_{2}$ acted as a better supporting matrix and prevented the aggregation of silver and allowed the controlled release of silver ions [163]. Nevertheless, continuous exposure to silver NPs may result in reduced effectiveness with developed silver resistance on MRSA [158], and high doses of silver NPs can delay wound recovery due to toxic effects on skin cells [164].

The antibacterial activities of metal oxide NPs have also been studied; examples include zinc oxide $(\mathrm{ZnO})$, copper oxide $(\mathrm{CuO})$, titanium dioxide $\left(\mathrm{TiO}_{2}\right)$, iron oxide $\left(\mathrm{Fe}_{2} \mathrm{O}_{3}\right)$, cerium oxide $(\mathrm{CeO})$, magnesium oxide $(\mathrm{MgO})$, and aluminum oxide $\left(\mathrm{Al}_{2} \mathrm{O}_{3}\right)$. $\mathrm{ZnO}$ NPs have been found to have better antibacterial activities and low toxicities in mammalian cells and to be more effective at inhibiting biofilm formation and the growth of E. faecalis, S. aureus, S. epidermidis, B. subtilis, and E. coli than the NPs of other metal oxides [154, 165]. ZnO NPs in combination with $\beta$-chitin dressings were found to treat skin wound infections effectively in rat models and to reduce biofilm formation. Furthermore, nanotextured 
TABLE 1: Nanoparticle-based solutions for prevention and treatment of biofilm associated-medical device infections.

\begin{tabular}{|c|c|c|c|}
\hline Material & Nanomaterial description & Antibiofilm devices & $\begin{array}{l}\text { Antimicrobial mechanism } \\
\text { of NPs }\end{array}$ \\
\hline Inorganic NPs & $\begin{array}{l}\text { Silver NPs }[12-15] \\
\text { Surface engineered gold } \\
\text { NPs [16] }\end{array}$ & $\begin{array}{l}\text { Urethral catheters, central } \\
\text { venous catheters } \\
\text { Ventricular drain catheters }\end{array}$ & $\begin{array}{l}\text { Released silver ion interacts } \\
\text { with sulfhydryl groups of } \\
\text { bacteria and interferes with } \\
\text { cell membrane integrity, } \\
\text { enzyme activities, } \\
\text { respiratory chains, and cell } \\
\text { proliferations [17]. } \\
\text { Highly positive surface } \\
\text { charge disrupts the network } \\
\text { of EPS. }\end{array}$ \\
\hline Organic NPs & $\begin{array}{l}\text { Quaternary ammonium } \\
\text { chitosan NPs [18] } \\
\text { PEG stabilized lipid NPs } \\
{[19]}\end{array}$ & Bone and dental cements & $\begin{array}{l}\text { Long cationic polymer } \\
\text { chains penetrate the cell } \\
\text { membrane and can induce } \\
\text { ion exchange to disrupt } \\
\text { biofilm }\end{array}$ \\
\hline
\end{tabular}

Ag-Ti composites [20]

Silver or antibiotic conjugated NPs $[21,22]$ NPs [23] Diamond like carbon-metal

Metallic/metal-polymer nanocomposites

Metallic/metal-polymer nanocomposites nanocomposites [24]

Silicone containing antibiotic loaded liposome [25]

Polymeric silver NPs [26]

Silver nanoparticle coated surfaces [27]

Polycationic NPs [28] Silver conjugated silicone

Highly positive surface charge disrupts the network of EPS
Face masks Heart valve Catheter against fungi Pedicle screws
Silver ions bound with deoxyribonucleic acid and interfere with electron transport, injuring bacterial enzymes and causing biofilm disruption
ZnO NP incorporated titanium implants [29] $\mathrm{TiO}_{2}$ nanotube arrays [30] Ag NP conjugated poly(ethylene glycol diacrylate)-co-acrylic acid (PEGDA-AA) hydrogel coatings on a Ti substrate Quaternary ammonium salts (QAS) loaded $\mathrm{TiO}_{2}$ nanotubes [31]

Ciprofloxacin-loaded nanochitosan coated $\mathrm{Ti}$ implants [32]

Polymeric NP based photodynamic therapy [33]
$\mathrm{ZnO}$ alter protein adsorptions and intracellular mechanisms Positive surface of QAS disintegrates the negatively charged bacteria Released ciprofloxacin inhibits enzymes including DNA gyrase, and

Orthopedic implants topoisomerase causes bacterial disruption Free radicals interact with endogenous molecular oxygen to produce ROS, superoxide hydroxyl radicals, and hydrogen peroxide damages bacteria membrane integrity and causes irreparable bacteria lysis

Ti implant surfaces with

ZnO NPs [34]

Nanostructured titania coating with Ag NPs [35]

Metallic/metal-polymer nanocomposites
Oral implants

Endodontic filling and dental adhesives
Antibiotic incorporated silk fibroin NPs coated titanium surface [36]

Nanosilver-endodontic filling and dental adhesives $[37,38]$
Direct contact, $\mathrm{ZnO}$ release, ROS generation Irreversible binding of gentamycin disrupts bacteria 
TABLE 1: Continued.

\begin{tabular}{|c|c|c|c|}
\hline Material & Nanomaterial description & Antibiofilm devices & $\begin{array}{l}\text { Antimicrobial mechanism } \\
\text { of NPs }\end{array}$ \\
\hline $\begin{array}{l}\text { Metallic/metal-polymer } \\
\text { nanocomposites }\end{array}$ & $\begin{array}{l}\text { Silica NPs [39] } \\
\text { Hydrogel containing Ag } \\
\text { NPs [40] } \\
\text { Zn-CuO nanocoating on } \\
\text { contact lenses [41] } \\
\text { Quaternized chitosan } \\
\text { loaded Ag NPs and } \\
\text { antifungal agent conjugated } \\
\text { graphene oxide [42] }\end{array}$ & Contact lenses & $\begin{array}{l}\text { Released Ag ions } \\
\text { disintegrate the bacteria } \\
\text { and inhibit biofilm } \\
\text { development } \\
\text { Voriconazole inhibits } \\
\text { ergosterol synthesis by } \\
\text { inhibiting 14-alpha sterol } \\
\text { demethylase which } \\
\text { produced antifungal } \\
\text { activity. }\end{array}$ \\
\hline
\end{tabular}

$\mathrm{ZnO}$ have been reported to have greater bacteriostatic and bacteria-resistant properties than titania nanophase [153]. However, $P$. aeruginosa and Proteus have been reported to exhibit zinc resistance $[166,167]$.

Nanosized $\mathrm{TiO}_{2}$ is also considered as nontoxic antibacterial material due to its inert nature as compared with other metal oxides. Usually, it considered a photocatalyst and is used for various environmentally related applications, such as self-cleaning and antifogging effects. Numerous reports have been issued on photocatalytic biofilm inhibition by $\mathrm{TiO}_{2}$ NPs. In addition, these NPs have shown promising antifungal biofilm activity on the surfaces of biomedical devices, especially against $C$. albicans [168]. The mechanism behind the antimicrobial effect of $\mathrm{TiO}_{2}$ NPs involves the production of ROS in microbial cells, oxidation of internal enzymes, and lipid peroxidation, which reduces respiratory activity and leads to cell death (Table 1) [169]. It has also been reported that mesoporous $\mathrm{TiO}_{2}$ NPs facilitate sustained release of attached bioactive materials and thus provide longterm antibiofilm activity [170].

$\mathrm{CuO}$ NPs exhibit effective antimicrobial activity against various bacteria, but they have less antibacterial activity than silver or zinc NPs, and hence higher concentrations are required to achieve desired antimicrobial effects, and at these concentrations $\mathrm{CuO}$ NPs could be toxic to mammalian cells [171-173]. Although $\mathrm{CuO}$ NPs have excellent antibacterial effects, their antibiofilm effects are limited by a narrow antibacterial window [174]. However, in combination they exhibit considerable activity; for example, $\mathrm{CuO}$ with $\mathrm{ZnO}$ NPs showed significant biofilm inhibitory activity in a NP coated tooth model [175].

Iron NPs are generally considered MRI contrast agents, but at $8 \mathrm{~nm}$ iron NPs eliminated S. epidermis infection on orthopedic implants [176]. Furthermore, antibiotic conjugated magnetic iron NPs showed higher antibacterial activity against E. faecalis in both its planktonic and biofilm forms than unconjugated magnetic iron NPs [177]. Catheters coated with $5 \mathrm{~nm}$ core-shell iron NPs showed biofilm resistance against $S$. aureus and $P$. aeruginosa, and these NPs were reported to be nontoxic and suggested for in vivo applications [178].

Gold NPs alone have little or no antibacterial activity [179]. Nevertheless, gold NPs bound to antibiotics [180], active compounds, or biomolecules [181] show considerable bactericidal and biofilm inhibitory activities against a variety of pathogens, including multidrug resistant strains [182]. Since gold NPs are nontoxic to cells, they have been conjugated with targeting molecules to achieve specific antibiofilm activities (Table 1) [183].

5.3. Organic Nanoparticles. Polymeric NPs and polymer based devices are engineered to provide antibacterial properties by releasing antibiotics, antimicrobial agents, or bacteriostatic peptides or by modifying their surfaces with alkyl pyrimidines or quaternary ammonium compounds to cause contact-killing (Table 1). The polycationic groups responsible for antimicrobial activity cause cell damage perhaps via an ion exchange interaction between bacteria and charged polymer surfaces resulting in the disruption of cellular membranes [184]. The polysaccharides of EPS interact with $\mathrm{SO}_{4}{ }^{-}$groups of functionalized polystyrene NPs by hydrophobic complexation, which disrupts bacterial biofilm formation [185]. A nanoporous polymer matrix composed of sodium dodecyl sulfate was found to have significant antibiofilm activity against E. coli. Likewise, vitamin E-conjugated cationic polymer crosslinked biodegradable hydrogels exhibit bactericidal and antifungal effects [118, 185, 186]. Levofloxacin (an antibiotic,) conjugated poly(lactic-co-glycolic acid) NPs coated with phosphatidyl choline nanohybrids exhibited enhanced antibiofilm activity against $E$. coli [187], and interestingly, a silicone functionalized PDMS surface (called the brush design) was highly effective against the bacterial and fungal biofilms of E. coli, S. aureus, and C. albicans without causing mammalian toxicity [188]. In addition, physicochemical surface modifications of titanium using polymers, such as polymethacrylic acid [189], polyurethane acetate [190], polyethylene oxide [191], or poly ethylene glycol (PEG) [192], prevented protein absorption and inhibited bacterial adherence $[193,194]$. Nitric oxide (NO) releasing silica NPs [195] have been utilized for their bactericidal effects on planktonic $P$. aeruginosa cells and used to treat biofilm-related wound infections in vivo in murine models and reduced bacterial loads of MRSA [196], A. baumannii [197], and C. albicans [198].

5.4. Metal-Polymer Nanocomposites. The mechanical properties of organic polymers are inadequate for device-related 
applications (Table 1), but they can be coated on metal surfaces by spin coating, dip coating, or layer-by-layer plasma polymerization [146]. Metal-polymer composites of silicone$\mathrm{TiO}_{2}$ NPs reduced the adhesion of $S$. aureus by 93\% versus untreated silicone [199], and gallium and zinc NPs incorporated in a polyether urethane mixed PEG scaffold reduced $P$. aeruginosa infection in mice via the controlled release of gallium NPs where zinc NPs were less effective [200].

5.5. Dendrimers. Dendrimers are three-dimensional structures with the ability to encapsulate hydrophilic and hydrophobic entities into the void spaces of their highly branched structures [201]. Synthesized low molecular weight peptide dendrimers showed antimicrobial activity against $E$. coli and S. aureus without additional antibiotics [202], and other studies demonstrated the disruption of $P$ aeruginosa attachment and prevention of its biofilm formation were due to the attachment of fucose-specific lectins (LecB) to fucosepeptide dendrimer ligands [203].

5.6. Cyclodextrins. Cyclodextrins (CDs) are cyclic organic compounds comprised of glucopyranose units and are used to solubilize hydrophobic compounds in aqueous media. It has been reported that CDs surface functionalized with polyethylene or polypropylene loaded with miconazole reduced C. albicans biofilm formation by $96 \%$ in vitro. Furthermore, gold surface functionalized CD grafted anidulafungin and thymol reduced the surface adherence of yeast and demonstrated fungicidal activity against $C$. albicans biofilms [204, 205]. Furthermore, at enhanced drug loading and retention, ciprofloxacin loaded CD-agar hydrogels showed broad antibacterial activity against $S$. aureus, S. epidermidis, P. aeruginosa, and E. coli and controlled drug release [206].

5.7. Lipid-Based NPs and Microemulsions. Since liposomes resemble biological cell membrane they have been utilized in many pharmaceutical applications, including biofilm-related therapies. Various drug loaded liposomes showed effective biofilm inhibition and quorum sensing disruption in vitro [207] and on clinical isolates [208] of E. coli, Acinetobacter lwoffi, A. baumannii, Bordetella bronchiseptica, Klebsiella pneumoniae, and $P$. aeruginosa, in which they reduced the productions of lipase, protease, and chitinase [209].

Solid lipid nanoparticle (SLN) formulations containing antimicrobial agents have been used to eradicate biofilmforming microorganisms. A SLN formulation containing PVA hydrogenated castor oil loaded with tilmicosin was used to treat S. aureus induced mastitis in a murine model [210] and a SLN formulation containing eugenol showed antifungal activity in a rat model oral candidiasis [211].

Microemulsions exhibited considerable antibiofilm activity against $P$. aeruginosa [212] and C. albicans [213] by disrupting cytoplasmic membranes, coagulating cytoplasm, and altering intracellular metabolism.

5.8. Responsive Smart Nanoparticles. A combination of external energy and energy absorbing NPs has been used as a therapeutic means of addressing antimicrobial infections (Table 1). The basic principle involves causing irreversible damage in pathogenic cells by activating metal NPs or polymer-based systems using external energy sources, such as visible light [214], temperature [215], near-infrared (NIR) radiation [216], or high frequency alternating magnetic fields (AMF) [217]. Gold, iron oxide, and graphene NPs have been utilized as photothermal agents that absorb NIR light and convert this into heat energy. Gold NPs of various shapes have been widely studied due to their excellent reactivity to NIR light, though this reactivity depends on particle size. Grampositive, Gram-negative, and mixed species of bacteria were inactivated thermally by exposing gold [218] or graphene NPs [219] to NIR. The temperature of NP-bacterial suspensions was found to be increased beyond the physiological limits of bacteria [220].

Nanoscale carriers have also been used for photodynamic therapy (PDT) to eradicate pathogens using light and photosensitizers. Exposure of photosensitizer-NP complexes to light causes the generation of cytotoxic ROS, which then trigger bacterial cell lysis in planktonic and biofilm forms. Conjugating photosensitizers on NPs were studied for their efficient PDT in terms of destroying targeted pathogens or biofilms [221]. NPs functionalized with porphyrin, methylene blue, or rose bengal significantly inactivated MRSA [222], C. albicans [223], and multispecies bacterial [224] biofilms. Although PDT has potential applications for the treatment of wound infections, several factors, such as the physicochemical properties of photosensitizers, the dosages delivered, light dosimetry, and control of drug release, currently limit its clinical applications.

Magnetic nanoparticles (MNPs) absorb electromagnetic radiation from high frequency AMF and efficiently transmit it in the form of localized heat, and the hyperthermia produced by MNPs has been used to destroy in vitro biofilms of $S$. aureus and $P$. aeruginosa [225]. In a recent study, it was demonstrated MNP hyperthermia efficiently disrupted $S$. aureus biofilms in vitro and in an in vivo mouse model of cutaneous wound infection [226].

\section{Antimicrobial and Antibiofilm Mechanisms of Nanoparticles}

The mechanisms underlying the antimicrobial effects of NPs are not completely understood and vary from the productions of oxidative and/or free radical formation stressors to DNA damage (Figure 1). Table 1 summarizes published findings on the antibacterial and antibiofilm properties of nanostructured materials, ranging from metals, polymers, and their composites. Mechanisms responsible for the antibacterial activity of NPs might involve particle size [227], shape [228], surface charge [229], or composition, and are believed to involve [159, 230-232], cell membrane alterations [233, 234], loss of respiratory activity [235], lipid peroxidation [236], ROS generation [237, 238], DNA unwinding [239], nitrosation of protein thiols [240], or disruptions of metabolic pathways [241, 242]. 


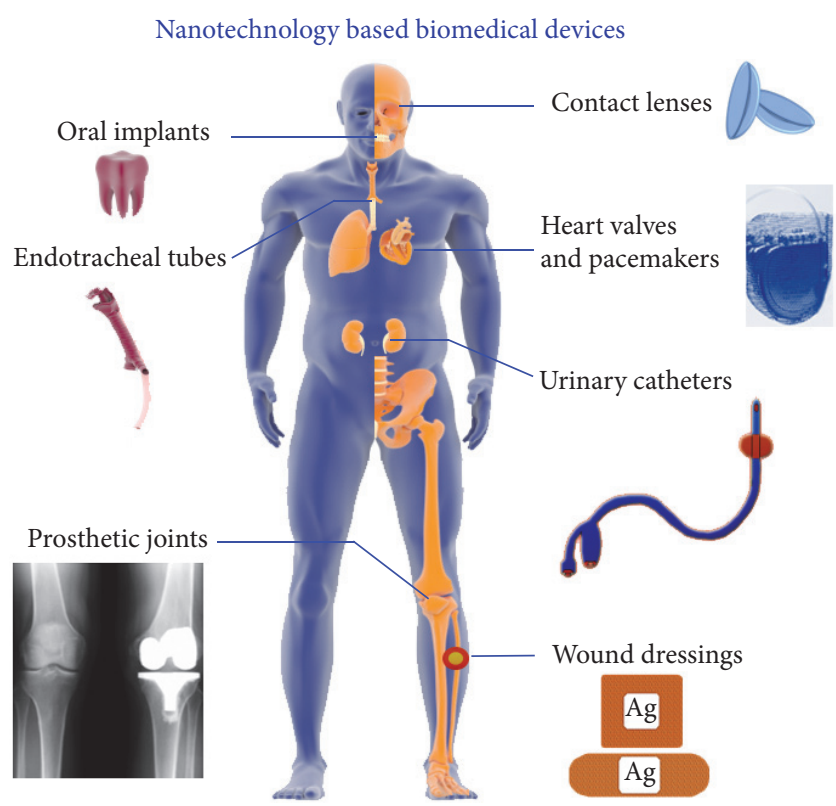

FIGURE 3: Summary of nanomaterial incorporating medical devices. Prosthetic joint image was reprinted with permission [58].

\section{Nanoparticle-Based Antibiofilm Devices}

Advances in the nanotechnology have resulted in the developments of high-performance, multifunctional, bioactive materials for biomedical devices. Given base materials with appropriate mechanical (e.g., hardness, stress, and Young's modulus) and tribological properties (e.g., wear resistance, adhesion, and friction), it would appear nanomaterial coatings are likely to result in novel multifunctional and biocompatible materials.

Various nanotools are being incorporated into the surfaces of biomedical devices to combat infections; Figure 3 and Table 1 provide more detail of the antimicrobial mechanisms involved (Figure 1).

\section{Future Perspectives}

Despite the advances made in the development of novel antibiofilm agents, devised biofilm treatment strategies are limited by their high costs and complexities, which means urgent development is required to identify cost-efficient alternatives. As is made clear by this review, recent developments in nanotechnology-based approaches aimed at preventing, controlling, and treating bacterial biofilm infections, especially of biomedical devices, are worthy of serious consideration. Different nanoparticle types and composites with demonstrated potential bactericidal and fungicidal properties have been shown to be efficient alternatives to antibiotics in terms of wound care and related biomedical issues. Nanomaterials are used as constituents of coatings, biomedical agents, and drug-delivery vehicles and of implant materials and research remains active in these areas. However, key issues like NP resistance and surface interactions between
NPs, biofilms, and hosts need to be resolved to ensure successful clinical applications.

Nanomaterial impregnations of antibiofilm devices are believed to provide extended antimicrobial effects and to be minimally toxic as compared with small molecule antimicrobials, which exhibit short term activities and are environmentally toxic. We hope that this review of the literature persuades the reader that nanomaterials and nanomaterialbased biomedical devices with broad spectrum antibiofilm activities will be produced such that they are potent, nontoxic, biocompatible, and cost-effective, and that these novel materials will establish new standards for the treatment and prevention of pathogenic biofilms.

\section{Competing Interests}

The authors report no conflict of interests regarding the publication of this paper.

\section{Acknowledgments}

This research was supported by National Research Foundation of Korea (NRF) grant funded by the Korea government (MSIP) (no. 2015R1A2A2A01004542 to Jintae Lee) and by the Priority Research Centers Program of the NRF funded by the Ministry of Education (no. 2014R1A6A1031189).

\section{References}

[1] C. B. Whitchurch, T. Tolker-Nielsen, P. C. Ragas, and J. S. Mattick, "Extracellular DNA required for bacterial biofilm formation," Science, vol. 295, no. 5559, p. 1487, 2002.

[2] K. Lewis, "Persister cells and the riddle of biofilm survival," Biochemistry, vol. 70, no. 2, pp. 267-274, 2005.

[3] T.-F. C. Mah and G. A. O’Toole, "Mechanisms of biofilm resistance to antimicrobial agents," Trends in Microbiology, vol. 9, no. 1, pp. 34-39, 2001.

[4] A. Dongari-Bagtzoglou, "Pathogenesis of mucosal biofilm infections: challenges and progress," Expert Review of AntiInfective Therapy, vol. 6, no. 2, pp. 201-208, 2008.

[5] Y. A. Nikolaev and V. K. Plakunov, "Biofilm-'city of microbes' or an analogue of multicellular organisms?” Microbiology, vol. 76, no. 2, pp. 125-138, 2007.

[6] B. Allegranzi, S. B. Nejad, C. Combescure et al., "Burden of endemic health-care-associated infection in developing countries: systematic review and meta-analysis," The Lancet, vol. 377, no. 9761, pp. 228-241, 2011.

[7] P. Zarb, B. Coignard, J. Griskeviciene et al., "The European Centre for Disease Prevention and Control (ECDC) pilot point prevalence survey of healthcare-associated infections and antimicrobial use," Euro Surveillance, vol. 17, no. 46, article 2, 2012.

[8] R. Torrecillas, M. Díaz, F. Barba, M. Miranda, F. Guitián, and J. S. Moya, "Synthesis and antimicrobial activity of a silverhydroxyapatite nanocomposite," Journal of Nanomaterials, vol. 2009, Article ID 498505, 6 pages, 2009.

[9] V. Stanić, D. Janaćković, S. Dimitrijević et al., "Synthesis of antimicrobial monophase silver-doped hydroxyapatite nanopowders for bone tissue engineering," Applied Surface Science, vol. 257, no. 9, pp. 4510-4518, 2011. 
[10] V. P. Pattani and J. W. Tunnell, "Nanoparticle-mediated photothermal therapy: a comparative study of heating for different particle types," Lasers in Surgery and Medicine, vol. 44, no. 8, pp. 675-684, 2012.

[11] G. Vallejo-Fernandez, O. Whear, A. G. Roca et al., "Mechanisms of hyperthermia in magnetic nanoparticles," Journal of Physics D: Applied Physics, vol. 46, no. 31, Article ID 312001, 2013.

[12] C. G. Kumar and P. Sujitha, "Green synthesis of Kocuranfunctionalized silver glyconanoparticles for use as antibiofilm coatings on silicone urethral catheters," Nanotechnology, vol. 25, no. 32, Article ID 325101, 2014.

[13] P. Lackner, R. Beer, G. Broessner et al., "Efficacy of silver nanoparticles-impregnated external ventricular drain catheters in patients with acute occlusive hydrocephalus," Neurocritical Care, vol. 8, no. 3, pp. 360-365, 2008.

[14] K. Wu, Y. Yang, Y. Zhang, J. Deng, and C. Lin, "A ntimicrobial activity and cytocompatibility of silver nanoparticles coated catheters via a biomimetic surface functionalization strategy," International Journal of Nanomedicine, vol. 10, pp. 7241-7252, 2015.

[15] L. E. Fisher, A. L. Hook, W. Ashraf et al., "Biomaterial modification of urinary catheters with antimicrobials to give longterm broadspectrum antibiofilm activity," Journal of Controlled Release, vol. 202, pp. 57-64, 2015.

[16] K. Giri, L. R. Yepes, B. Duncan et al., "Targeting bacterial biofilms via surface engineering of gold nanoparticles," RSC Advances, vol. 5, no. 128, pp. 105551-105559, 2015.

[17] S. Taheri, K. Vasilev, and P. Majewski, "Silver nanoparticles: synthesis, antimicrobial coatings, and applications for medical devices," Recent Patents on Materials Science, vol. 8, no. 2, pp. 166-175, 2015.

[18] Z. Shi, K. G. Neoh, E. T. Kang, and W. Wang, "Antibacterial and mechanical properties of bone cement impregnated with chitosan nanoparticles," Biomaterials, vol. 27, no. 11, pp. 24402449, 2006.

[19] L.-M. Sun, C.-L. Zhang, and P. Li, "Characterization, antibiofilm, and mechanism of action of novel PEG-stabilized lipid nanoparticles loaded with terpinen-4-ol," Journal of Agricultural and Food Chemistry, vol. 60, no. 24, pp. 6150-6156, 2012.

[20] Y. Li, P. Leung, L. Yao, Q. W. Song, and E. Newton, "Antimicrobial effect of surgical masks coated with nanoparticles," Journal of Hospital Infection, vol. 62, no. 1, pp. 58-63, 2006.

[21] L. Zhang, S. Keogh, and C. M. Rickard, "Reducing the risk of infection associated with vascular access devices through nanotechnology: a perspective," International Journal of Nanomedicine, vol. 8, pp. 4453-4466, 2013.

[22] J. T. T. Angelina, S. Ganesan, T. M. R. Panicker, R. Narayani, M. Paul Korath, and K. Jagadeesan, "Pulsed laser deposition of silver nanoparticles on prosthetic heart valve material to prevent bacterial infection," Materials Technology, 2016.

[23] G. L. Grunkemeier, R. Jin, and A. Starr, "Prosthetic heart valves: objective performance criteria versus randomized clinical trial," The Annals of Thoracic Surgery, vol. 82, no. 3, pp. 776-780, 2006.

[24] M. Andara, A. Agarwal, D. Scholvin et al., "Hemocompatibility of diamondlike carbon-metal composite thin films," Diamond and Related Materials, vol. 15, no. 11-12, pp. 1941-1948, 2006.

[25] C. J. Walraven and S. A. Lee, "Antifungal lock therapy", Antimicrobial Agents and Chemotherapy, vol. 57, no. 1, pp. 1-8, 2013.

[26] C. H. Ho, E. K. Odermatt, I. Berndt, and J. C. Tiller, "Longterm active antimicrobial coatings for surgical sutures based on silver nanoparticles and hyperbranched polylysine," Journal of
Biomaterials Science, Polymer Edition, vol. 24, no. 13, pp. 1589$1600,2013$.

[27] D. B. Hazer, M. Sakar, Y. Dere, G. Altinkanat, M. I. Ziyal, and B. Hazer, "Polymer-based silver nanoparticle coated pedicle screws inhibits biofilm formation-a novel experimental model in rabbits," Global Spine Journal, vol. 6, no. 1, supplement, p. GO226, 2016.

[28] L. Atar-Froyman, A. Sharon, E. I. Weiss et al., "Anti-biofilm properties of wound dressing incorporating nonrelease polycationic antimicrobials," Biomaterials, vol. 46, pp. 141-148, 2015.

[29] E. Elizabeth, G. Baranwal, A. G. Krishnan, D. Menon, and M. Nair, "ZnO nanoparticle incorporated nanostructured metallic titanium for increased mesenchymal stem cell response and antibacterial activity," Nanotechnology, vol. 25, no. 11, Article ID 115101, 2014.

[30] Z. Peng, J. Ni, K. Zheng et al., "Dual effects and mechanism of $\mathrm{TiO}_{2}$ nanotube arrays in reducing bacterial colonization and enhancing C3H10T1/2 cell adhesion," International Journal of Nanomedicine, vol. 8, pp. 3093-3105, 2013.

[31] X. Chen, K. Cai, J. Fang et al., "Dual action antibacterial $\mathrm{TiO}_{2}$ nanotubes incorporated with silver nanoparticles and coated with a quaternary ammonium salt (QAS)," Surface and Coatings Technology, vol. 216, pp. 158-165, 2013.

[32] E. De Giglio, A. Trapani, D. Cafagna et al., "Ciprofloxacinloaded chitosan nanoparticles as titanium coatings: a valuable strategy to prevent implant-associated infections," Nano Biomedicine and Engineering, vol. 4, no. 4, pp. 163-169, 2012.

[33] L. de Freitas, G. Calixto, M. Chorilli et al., "Polymeric nanoparticle-based photodynamic therapy for chronic periodontitis in vivo," International Journal of Molecular Sciences, vol. 17, no. 5, p. 769, 2016.

[34] E. H. Abdulkareem, K. Memarzadeh, R. P. Allaker, J. Huang, J. Pratten, and D. Spratt, "Anti-biofilm activity of zinc oxide and hydroxyapatite nanoparticles as dental implant coating materials," Journal of Dentistry, vol. 43, no. 12, pp. 1462-1469, 2015.

[35] L. Zhao, H. Wang, K. Huo et al., "Antibacterial nano-structured titania coating incorporated with silver nanoparticles," Biomaterials, vol. 32, no. 24, pp. 5706-5716, 2011.

[36] S. Sharma, S. Bano, A. S. Ghosh et al., "Silk fibroin nanoparticles support in vitro sustained antibiotic release and osteogenesis on titanium surface," Nanomedicine: Nanotechnology, Biology and Medicine, vol. 12, no. 5, pp. 1193-1204, 2016.

[37] A. P. R. Magalhães, L. B. Santos, L. G. Lopes et al., "Nanosilver application in dental cements," ISRN Nanotechnology, vol. 2012, Article ID 365438, 6 pages, 2012.

[38] S.-J. Ahn, S.-J. Lee, J.-K. Kook, and B.-S. Lim, "Experimental antimicrobial orthodontic adhesives using nanofillers and silver nanoparticles," Dental Materials, vol. 25, no. 2, pp. 206-213, 2009.

[39] W. Qu, J. M. M. Hooymans, J. Qiu et al., "Nonadhesive, silica nanoparticles-based brush-coated contact lens cases-compromising between ease of cleaning and microbial transmission to contact lenses," Journal of Biomedical Materials Research Part B: Applied Biomaterials, vol. 101, no. 4, pp. 640-647, 2013.

[40] B. S. F. Bazzaz, B. Khameneh, M.-M. Jalili-Behabadi, B. Malaekeh-Nikouei, and S. A. Mohajeri, "Preparation, characterization and antimicrobial study of a hydrogel (soft contact lens) material impregnated with silver nanoparticles," Contact Lens and Anterior Eye, vol. 37, no. 3, pp. 149-152, 2014. 
[41] R. Tuby, S. Gutfreund, I. Perelshtein et al., "Fabrication of a stable and efficient antibacterial nanocoating of $\mathrm{Zn}-\mathrm{CuO}$ on contact lenses," ChemNanoMat, vol. 2, no. 6, pp. 547-551, 2016.

[42] J.-F. Huang, J. Zhong, G.-P. Chen et al., "A hydrogel-based hybrid theranostic contact lens for fungal keratitis," ACS Nano, vol. 10, no. 7, pp. 6464-6473, 2016.

[43] J. W. Costerton, Z. Lewandowski, D. E. Caldwell, D. R. Korber, and H. M. Lappin-Scott, "Microbial biofilms," Annual Review of Microbiology, vol. 49, no. 1, pp. 711-745, 1995.

[44] D. Estivill, A. Arias, A. Torres-Lana, A. J. Carrillo-Muñoz, and M. P. Arévalo, "Biofilm formation by five species of Candida on three clinical materials," Journal of Microbiological Methods, vol. 86, no. 2, pp. 238-242, 2011.

[45] S. Neethirajan, M. A. Clond, and A. Vogt, "Medical biofilmsnanotechnology approaches," Journal of Biomedical Nanotechnology, vol. 10, no. 10, pp. 2806-2827, 2014.

[46] M. Kostakioti, M. Hadjifrangiskou, and S. J. Hultgren, "Bacterial biofilms: development, dispersal, and therapeutic strategies in the dawn of the postantibiotic era," Cold Spring Harbor Perspectives in Medicine, vol. 3, no. 4, article a010306, 2013.

[47] I. Banerjee, R. C. Pangule, and R. S. Kane, "Antifouling coatings: recent developments in the design of surfaces that prevent fouling by proteins, bacteria, and marine organisms," Advanced Materials, vol. 23, no. 6, pp. 690-718, 2011.

[48] V. Kochkodan and N. Hilal, "A comprehensive review on surface modified polymer membranes for biofouling mitigation," Desalination, vol. 356, pp. 187-207, 2015.

[49] H. Zhang and M. Chiao, "Anti-fouling coatings of poly (dimethylsiloxane) devices for biological and biomedical applications," Journal of Medical and Biological Engineering, vol. 35, no. 2, pp. 143-155, 2015.

[50] C.-J. Jung, C.-Y. Yeh, C.-T. Shun et al., "Platelets enhance biofilm formation and resistance of endocarditis-inducing streptococci on the injured heart valve," Journal of Infectious Diseases, vol. 205, no. 7, pp. 1066-1075, 2012.

[51] L. Hall-Stoodley, J. W. Costerton, and P. Stoodley, "Bacterial biofilms: from the natural environment to infectious diseases," Nature Reviews Microbiology, vol. 2, no. 2, pp. 95-108, 2004.

[52] F. Götz, "Staphylococcus and biofilms," Molecular Microbiology, vol. 43, no. 6, pp. 1367-1378, 2002.

[53] C. Vuong, S. Kocianova, Y. Yao, A. B. Carmody, and M. Otto, "Increased colonization of indwelling medical devices by quorum-sensing mutants of Staphylococcus epidermidis in vivo," Journal of Infectious Diseases, vol. 190, no. 8, pp. 1498-1505, 2004.

[54] A. L. Spoering and K. Lewis, "Biofilms and planktonic cells of Pseudomonas aeruginosa have similar resistance to killing by antimicrobials," Journal of Bacteriology, vol. 183, no. 23, pp. 6746-6751, 2001.

[55] C. Von Eiff, C. Heilmann, and G. Peters, "New aspects in the molecular basis of polymer-associated infections due to staphylococci," European Journal of Clinical Microbiology and Infectious Diseases, vol. 18, no. 12, pp. 843-846, 1999.

[56] S. Niveditha, S. Pramodhini, S. Umadevi, S. Kumar, and S. Stephen, "The isolation and the biofilm formation of uropathogens in the patients with catheter associated urinary tract infections (UTIs)," Journal of Clinical and Diagnostic Research, vol. 6, no. 9, pp. 1478-1482, 2012.

[57] V. Antoci Jr., C. S. Adams, J. Parvizi et al., "The inhibition of Staphylococcus epidermidis biofilm formation by vancomycinmodified titanium alloy and implications for the treatment of periprosthetic infection," Biomaterials, vol. 29, no. 35, pp. 46844690, 2008.

[58] E. McPherson, M. Dipane, and S. Sherif, "Dissolvable antibiotic beads in treatment of periprosthetic joint infection and revision arthroplasty-The Use of Synthetic Pure Calcium Sulfate (Stimulan ${ }^{\circledR}$ ) impregnated with vancomycin \& tobramycin," Reconstructive Review, vol. 3, no. 1, 2013.

[59] S. N. Hocevar, J. R. Edwards, T. C. Horan, G. C. Morrell, M. Iwamoto, and F. C. Lessa, "Device-associated infections among neonatal intensive care unit patients: Incidence and associated pathogens reported to the national healthcare Safety Network, 2006-2008," Infection Control and Hospital Epidemiology, vol. 33, no. 12, pp. 1200-1206, 2012.

[60] S. Hopkins, K. Shaw, and L. Simpson, English National Point Prevalence Survey on Healthcare-Associated Infections and Antimicrobial Use, Health Protection Agency, London, UK, 2011.

[61] S. Saint, C. P. Kowalski, S. R. Kaufman et al., "Preventing hospital-acquired urinary tract infection in the United States: A National Study," Clinical Infectious Diseases, vol. 46, no. 2, pp. 243-250, 2008.

[62] E. van Kleef, J. V. Robotham, M. Jit, S. R. Deeny, and W. J. Edmunds, "Modelling the transmission of healthcare associated infections: a systematic review," BMC Infectious Diseases, vol. 13, article 294, 2013.

[63] R. D. Scott, The Direct Medical Costs of Healthcare-Associated Infections in US Hospitals and the Benefits of Prevention, Division of Healthcare Quality Promotion National Center for Preparedness, Detection, and Control of Infectious Diseases, Centers for Disease Control and Prevention, 2009.

[64] K. Ruellan, J. H. M. Frijns, G. V. Bloemberg et al., "Detection of bacterial biofilm on cochlear implants removed because of device failure, without evidence of infection," Otology and Neurotology, vol. 31, no. 8, pp. 1320-1324, 2010.

[65] J. A. T. Sandoe, I. R. Witherden, J. H. Cove, J. Heritage, and M. H. Wilcox, "Correlation between enterococcal biofilm formation in vitro and medical-device-related infection potential in vivo," Journal of Medical Microbiology, vol. 52, no. 7, pp. 547-550, 2003.

[66] J. Rogers, D. I. Norkett, P. Bracegirdle et al., "Examination of biofilm formation and risk of infection associated with the use of urinary catheters with leg bags," Journal of Hospital Infection, vol. 32, no. 2, pp. 105-115, 1996.

[67] P. Stoodley, S. Kathju, F. Z. Hu et al., "Molecular and imaging techniques for bacterial biofilms in joint arthroplasty infections," Clinical Orthopaedics and Related Research, no. 437, pp. 31-40, 2005.

[68] F. Gemmel, H. Van Den Wyngaert, C. Love, M. M. Welling, P. Gemmel, and C. J. Palestro, "Prosthetic joint infections: radionuclide state-of-the-art imaging," European Journal of Nuclear Medicine and Molecular Imaging, vol. 39, no. 5, pp. 892909, 2012.

[69] C. L. Parsons, P. C. Stein, M. K. Dobke, C. P. Virden, and D. H. Frank, "Diagnosis and therapy of subclinically infected prostheses," Journal of the American College of Surgeon, vol. 177, no. 5, pp. 504-506, 1993.

[70] M. J. Elder, F. Stapleton, E. Evans, and J. K. G. Dart, "Biofilmrelated infections in ophthalmology," Eye, vol. 9, no. 1, pp. 102109, 1995.

[71] T. F. Moriarty, U. Schlegel, S. Perren, and R. G. Richards, "Infection in fracture fixation: can we influence infection rates through implant design?" Journal of Materials Science: Materials in Medicine, vol. 21, no. 3, pp. 1031-1035, 2010. 
[72] D. G. Hargreaves, A. Pajkos, A. K. Deva, K. Vickery, S. L. Filan, and M. A. Tonkin, "The re-attachment of tendon and ligament avulsions," Journal of Hand Surgery, vol. 27, no. 4, pp. 337-341, 2002.

[73] A. Pajkos, A. K. Deva, K. Vickery, C. Cope, L. Chang, and Y. E. Cossart, "Detection of subclinical infection in significant breast implant capsules," Plastic and Reconstructive Surgery, vol. 111, no. 5, pp. 1605-1611, 2003.

[74] C. P. Virden, M. K. Dobke, P. Stein, C. L. Parsons, and D. H. Frank, "Subclinical infection of the silicone breast implant surface as a possible cause of capsular contracture," Aesthetic Plastic Surgery, vol. 16, no. 2, pp. 173-179, 1992.

[75] G. M. Viola and R. O. Darouiche, "Cardiovascular implantable device infections," Current Infectious Disease Reports, vol. 13, no. 4, pp. 333-342, 2011.

[76] A. Pajkos, K. Vickery, and Y. Cossart, "Is biofilm accumulation on endoscope tubing a contributor to the failure of cleaning and decontamination?" Journal of Hospital Infection, vol. 58, no. 3, pp. 224-229, 2004.

[77] J. J. Y. Sung, "Bacterial biofilm and clogging of biliary stents," Journal of Industrial Microbiology, vol. 15, no. 3, pp. 152-155, 1995.

[78] R. O. Darouiche, "Treatment of infections associated with surgical implants," The New England Journal of Medicine, vol. 350, no. 14, pp. 1422-1429, 2004.

[79] K. H. Ward, M. E. Olson, K. Lam, and J. W. Costerton, "Mechanism of persistent infection associated with peritoneal implants," Journal of Medical Microbiology, vol. 36, no. 6, pp. 406-413, 1992.

[80] H. W. Boucher, G. H. Talbot, J. S. Bradley et al., "Bad bugs, no drugs: no ESKAPE! An update from the Infectious Diseases Society of America," Clinical Infectious Diseases, vol. 48, no. 1, pp. 1-12, 2009.

[81] V. D. Rosenthal, D. G. Maki, S. Jamulitrat et al., "International Nosocomial Infection Control Consortium (INICC) report, data summary for 2003-2008, issued June 2009," American Journal of Infection Control, vol. 38, no. 2, pp. 95.e2-104.e2, 2010.

[82] N. P. O'Grady, “Review: paired quantitative blood cultures most accurately detect intravascular device-related bloodstream infection," ACP Journal Club, vol. 143, no. 3, p. 77, 2005.

[83] R. M. Donlan, R. Murga, M. Bell et al., "Protocol for detection of biofilms on needleless connectors attached to central venous catheters," Journal of Clinical Microbiology, vol. 39, no. 2, pp. 750-753, 2001.

[84] I. Raad, W. Costerton, U. Sabharwal, M. Sacilowski, E. Anaissie, and G. P. Bodey, "Ultrastructural analysis of indwelling vascular catheters: a quantitative relationship between luminal colonization and duration of placement," Journal of Infectious Diseases, vol. 168, no. 2, pp. 400-407, 1993.

[85] D. J. Stickler, "Bacterial biofilms in patients with indwelling urinary catheters," Nature Clinical Practice Urology, vol. 5, no. 11, pp. 598-608, 2008.

[86] S. L. Percival, N. A. Sabbuba, P. Kite, and D. J. Stickler, “The effect of EDTA instillations on the rate of development of encrustation and biofilms in Foley catheters," Urological Research, vol. 37, no. 4, pp. 205-209, 2009.

[87] D. Kaye and M. Hessen, "Infections associated with foreign bodies in the urinary tract," in Infections Associated with Indwelling Medical Devices, pp. 291-307, American Society for Microbiology, Washington, DC, USA, 1994.
[88] D. J. Stickler and S. D. Morgan, "Observations on the development of the crystalline bacterial biofilms that encrust and block Foley catheters," Journal of Hospital Infection, vol. 69, no. 4, pp. 350-360, 2008.

[89] S. S. Talsma, "Biofilms on medical devices," Home Healthcare Nurse, vol. 25, no. 9, pp. 589-594, 2007.

[90] T. T. Bauer, A. Torres, R. Ferrer, C. M. Heyer, G. SchultzeWerninghaus, and K. Rasche, "Biofilm formation in endotracheal tubes. Association between pneumonia and the persistence of pathogens," Monaldi Archives for Chest DiseasePulmonary Series, vol. 57, no. 1, pp. 84-87, 2002.

[91] I. Vandecandelaere and T. Coenye, "Microbial composition and antibiotic resistance of biofilms recovered from endotracheal tubes of mechanically ventilated patients," in Biofilm-Based Healthcare-Associated Infections, pp. 137-155, Springer, 2015.

[92] I. Vandecandelaere, N. Matthijs, F. van Nieuwerburgh et al., "Assessment of microbial diversity in biofilms recovered from endotracheal tubes using culture dependent and independent approaches," PLoS ONE, vol. 7, no. 6, article e38401, 2012.

[93] D. J. McMinn, K. I. Snell, J. Daniel, R. B. Treacy, P. B. Pynsent, and R. D. Riley, "Mortality and implant revision rates of hip arthroplasty in patients with osteoarthritis: registry based cohort study," British Medical Journal, vol. 344, Article ID e3319, 2012.

[94] J. L. Del Pozo and R. Patel, "Infection associated with prosthetic joints," The New England Journal of Medicine, vol. 361, no. 8, pp. 787-794, 2009.

[95] W. Vongpatanasin, L. D. Hillis, and R. A. Lange, "Prosthetic heart valves," The New England Journal of Medicine, vol. 335, no. 6, pp. 407-416, 1996.

[96] M. C. Chifiriuc, O. Banu, C. Bleotu, V. Lazar, and V. Lazăr, "Interaction of bacteria isolated from clinical biofilms with cardiovascular prosthetic devices and eukaryotic cells," Anaerobe, vol. 17, no. 6, pp. 419-421, 2011.

[97] S. Bosio, S. Leekha, S. I. Gamb, A. J. Wright, C. L. Terrell, and D. V. Miller, "Mycobacterium fortuitum prosthetic valve endocarditis: a case for the pathogenetic role of biofilms," Cardiovascular Pathology, vol. 21, no. 4, pp. 361-364, 2012.

[98] L. B. Szczotka-Flynn, Y. Imamura, J. Chandra et al., "Increased resistance of contact lens-related bacterial biofilms to antimicrobial activity of soft contact lens care solutions," Cornea, vol. 28, no. 8, pp. 918-926, 2009.

[99] X. Gu, J. D. Jennings, J. Snarr, V. Chaudhary, J. E. Pollard, and P. B. Savage, "Optimization of ceragenins for prevention of bacterial colonization of hydrogel contact lenses," Investigative Ophthalmology and Visual Science, vol. 54, no. 9, pp. 6217-6223, 2013.

[100] K. J. Bozic, S. M. Kurtz, E. Lau, K. Ong, D. T. P. Vail, and D. J. Berry, "The epidemiology of revision total hip arthroplasty in the United States," The Journal of Bone \& Joint SurgeryAmerican Volume, vol. 91, no. 1, pp. 128-133, 2009.

[101] G. N. Belibasakis, "Microbiological and immuno-pathological aspects of peri-implant diseases," Archives of Oral Biology, vol. 59, no. 1, pp. 66-72, 2014.

[102] M. Gahlert, T. Gudehus, S. Eichhorn, E. Steinhauser, H. Kniha, and W. Erhardt, "Biomechanical and histomorphometric comparison between zirconia implants with varying surface textures and a titanium implant in the maxilla of miniature pigs," Clinical Oral Implants Research, vol. 18, no. 5, pp. 662-668, 2007. 
[103] S. Grassi, A. Piattelli, D. S. Ferrari et al., "Histologic evaluation of human bone integration on machined and sandblasted acidetched titanium surfaces in type IV bone," Journal of Oral Implantology, vol. 33, no. 1, pp. 8-12, 2007.

[104] C. Mangano, A. De Rosa, V. Desiderio et al., "The osteoblastic differentiation of dental pulp stem cells and bone formation on different titanium surface textures," Biomaterials, vol. 31, no. 13, pp. 3543-3551, 2010.

[105] B. R. Burkhardt, M. Fried, P. L. Schnur, and J. J. Tofield, "Capsules, infection, and intraluminal antibiotics," Plastic \& Reconstructive Surgery, vol. 68, no. 1, pp. 43-47, 1981.

[106] S. Bartsich, J. A. Ascherman, S. Whittier, C. A. Yao, and C. Rohde, "The breast: a clean-contaminated surgical site," Aesthetic Surgery Journal, vol. 31, no. 7, pp. 802-806, 2011.

[107] E. H. Courtiss, R. M. Goldwyn, and G. W. Anastasi, "The fate of breast implants with infections around them," Plastic and Reconstructive Surgery, vol. 63, no. 6, pp. 812-816, 1979.

[108] J. W. Thornton, L. C. Argenta, K. D. McClatchey, and M. W. Marks, "Studies on the endogenous flora of the human breast," Annals of Plastic Surgery, vol. 20, no. 1, pp. 39-42, 1988.

[109] K. G. Neoh and E. T. Kang, "Combating bacterial colonization on metals via polymer coatings: relevance to marine and medical applications," ACS Applied Materials and Interfaces, vol. 3, no. 8, pp. 2808-2819, 2011.

[110] H. Shintani, "Modification of medical device surface to attain anti-infection," Trends in Biomaterials and Artificial Organs, vol. 18, no. 1, pp. 1-8, 2004.

[111] C. S. Kwok, T. A. Horbett, and B. D. Ratner, "Design of infectionresistant antibiotic-releasing polymers: II. Controlled release of antibiotics through a plasma-deposited thin film barrier," Journal of Controlled Release, vol. 62, no. 3, pp. 301-311, 1999.

[112] R. N. S. Sodhi, V. P. Sahi, and M. W. Mittelman, "Application of electron spectroscopy and surface modification techniques in the development of anti-microbial coatings for medical devices," Journal of Electron Spectroscopy and Related Phenomena, vol. 121, no. 1-3, pp. 249-264, 2001.

[113] L. Li, S. Molin, L. Yang, and S. Ndoni, "Sodium dodecyl sulfate (SDS)-loaded nanoporous polymer as anti-biofilm surface coating material," International Journal of Molecular Sciences, vol. 14, no. 2, pp. 3050-3064, 2013.

[114] B. Gottenbos, H. C. van der Mei, F. Klatter, P. Nieuwenhuis, and H. J. Busscher, "In vitro and in vivo antimicrobial activity of covalently coupled quaternary ammonium silane coatings on silicone rubber," Biomaterials, vol. 23, no. 6, pp. 1417-1423, 2002.

[115] E. B. H. Hume, J. Baveja, B. Muir et al., "The control of Staphylococcus epidermidis biofilm formation and in vivo infection rates by covalently bound furanones," Biomaterials, vol. 25, no. 20, pp. 5023-5030, 2004.

[116] S. V. Pavlukhina, J. B. Kaplan, L. Xu et al., "Noneluting enzymatic antibiofilm coatings," ACS Applied Materials and Interfaces, vol. 4, no. 9, pp. 4708-4716, 2012.

[117] X. Khoo, P. Hamilton, G. A. O’Toole, B. D. Snyder, D. J. Kenan, and M. W. Grinstaff, "Directed assembly of PEGylated-peptide coatings for infection-resistant titanium metal," Journal of the American Chemical Society, vol. 131, no. 31, pp. 10992-10997, 2009.

[118] A. L. Z. Lee, V. W. L. Ng, W. Wang, J. L. Hedrick, and Y. Y. Yang, "Block copolymer mixtures as antimicrobial hydrogels for biofilm eradication," Biomaterials, vol. 34, no. 38, pp. 10278-10286, 2013.
[119] C. R. Arciola, D. Campoccia, P. Speziale, L. Montanaro, and J. W. Costerton, "Biofilm formation in Staphylococcus implant infections. A review of molecular mechanisms and implications for biofilm-resistant materials," Biomaterials, vol. 33, no. 26, pp. 5967-5982, 2012.

[120] J. Hasan, R. J. Crawford, and E. P. Ivanova, "Antibacterial surfaces: the quest for a new generation of biomaterials," Trends in Biotechnology, vol. 31, no. 5, pp. 295-304, 2013.

[121] C. Tedjo, K. G. Neoh, E. T. Kang, N. Fang, and V. Chan, "Bacteria-surface interaction in the presence of proteins and surface attached poly (ethylene glycol) methacrylate chains," Journal of Biomedical Materials Research Part A, vol. 82, no. 2, pp. 479-491, 2007.

[122] I. C. S. Fernández, H. C. van der Mei, M. J. Lochhead, D. W. Grainger, and H. J. Busscher, "The inhibition of the adhesion of clinically isolated bacterial strains on multi-component crosslinked poly(ethylene glycol)-based polymer coatings," Biomaterials, vol. 28, no. 28, pp. 4105-4112, 2007.

[123] K. D. Park, Y. S. Kim, D. K. Han et al., "Bacterial adhesion on PEG modified polyurethane surfaces," Biomaterials, vol. 19, no. 7-9, pp. 851-859, 1998.

[124] A. Roosjen, H. C. van der Mei, H. J. Busscher, and W. Norde, "Microbial adhesion to poly (ethylene oxide) brushes: influence of polymer chain length and temperature," Langmuir, vol. 20, no. 25, pp. 10949-10955, 2004.

[125] G. D. Bixler and B. Bhushan, "Biofouling: lessons from nature, Philosophical Transactions of the Royal Society of London A: Mathematical," Physical and Engineering Sciences, vol. 370, no. 1967, pp. 2381-2417, 2012.

[126] E. Celia, T. Darmanin, E. Taffin de Givenchy, S. Amigoni, and F. Guittard, "Recent advances in designing superhydrophobic surfaces," Journal of Colloid and Interface Science, vol. 402, pp. 1-18, 2013.

[127] V. A. Ganesh, H. K. Raut, A. S. Nair, and S. Ramakrishna, "A review on self-cleaning coatings," Journal of Materials Chemistry, vol. 21, no. 41, pp. 16304-16322, 2011.

[128] R. B. Pernites, C. M. Santos, M. Maldonado, R. R. Ponnapati, D. F. Rodrigues, and R. C. Advincula, "Tunable protein and bacterial cell adsorption on colloidally templated superhydrophobic polythiophene films," Chemistry of Materials, vol. 24, no. 5, pp. 870-880, 2012.

[129] K. K. Chung, J. F. Schumacher, E. M. Sampson, R. A. Burne, P. J. Antonelli, and A. B. Brennan, "Impact of engineered surface microtopography on biofilm formation of Staphylococcus aureus," Biointerphases, vol. 2, no. 2, pp. 89-94, 2007.

[130] M. L. Carman, T. G. Estes, A. W. Feinberg et al., "Engineered antifouling microtopographies-correlating wettability with cell attachment," Biofouling, vol. 22, no. 1, pp. 11-21, 2006.

[131] P. Appendini and J. H. Hotchkiss, "Review of antimicrobial food packaging," Innovative Food Science and Emerging Technologies, vol. 3, no. 2, pp. 113-126, 2002.

[132] I. Francolini, P. Norris, A. Piozzi, G. Donelli, and P. Stoodley, "Usnic acid, a natural antimicrobial agent able to inhibit bacterial biofilm formation on polymer surfaces," Antimicrobial Agents and Chemotherapy, vol. 48, no. 11, pp. 4360-4365, 2004.

[133] M. A. Rojas-Graü, R. Soliva-Fortuny, and O. Martín-Belloso, "Edible coatings to incorporate active ingredients to fresh-cut fruits: a review," Trends in Food Science and Technology, vol. 20, no. 10 , pp. 438-447, 2009.

[134] J. C. Tiller, C.-J. Liao, K. Lewis, and A. M. Klibanov, "Designing surfaces that kill bacteria on contact," Proceedings of the 
National Academy of Sciences of the United States of America, vol. 98, no. 11, pp. 5981-5985, 2001.

[135] J. C. J. Webb and R. F. Spencer, "The role of polymethylmethacrylate bone cement in modern orthopaedic surgery," Journal of Bone and Joint Surgery-Series B, vol. 89, no. 7, pp. 851-857, 2007.

[136] R. O. Darouiche, "In vivo efficacy of antimicrobial-coated devices," The Journal of Bone and Joint Surgery, vol. 90, no. 8, pp. 1785-1786, 2008.

[137] T. Jaeblon, "Polymethylmethacrylate: properties and contemporary uses in orthopaedics," Journal of the American Academy of Orthopaedic Surgeons, vol. 18, no. 5, pp. 297-305, 2010.

[138] M. C. B. Ammons, L. S. Ward, and G. A. James, "Antibiofilm efficacy of a lactoferrin/xylitol wound hydrogel used in combination with silver wound dressings," International Wound Journal, vol. 8, no. 3, pp. 268-273, 2011.

[139] A. E. Zeraik and M. Nitschke, "Biosurfactants as agents to reduce adhesion of pathogenic bacteria to polystyrene surfaces: effect of temperature and hydrophobicity," Current Microbiology, vol. 61, no. 6, pp. 554-559, 2010.

[140] I. A. Rojas, J. B. Slunt, and D. W. Grainger, "Polyurethane coatings release bioactive antibodies to reduce bacterial adhesion," Journal of Controlled Release, vol. 63, no. 1-2, pp. 175-189, 2000.

[141] L. Cegelski, J. S. Pinkner, N. D. Hammer et al., "Small-molecule inhibitors target Escherichia coli amyloid biogenesis and biofilm formation," Nature Chemical Biology, vol. 5, no. 12, pp. 913-919, 2009.

[142] P. Klemm, V. Hancock, and M. A. Schembri, "Mellowing out: adaptation to commensalism by Escherichia coli asymptomatic bacteriuria strain 83972," Infection and Immunity, vol. 75, no. 8, pp. 3688-3695, 2007.

[143] O. Simonetti, O. Cirioni, R. Ghiselli et al., "RNAIII-inhibiting peptide enhances healing of wounds infected with methicillinresistant Staphylococcus aureus," Antimicrobial Agents and Chemotherapy, vol. 52, no. 6, pp. 2205-2211, 2008.

[144] O. Rendueles and J.-M. Ghigo, "Multi-species biofilms: how to avoid unfriendly neighbors," FEMS Microbiology Reviews, vol. 36, no. 5, pp. 972-989, 2012.

[145] P. N. Danese, "Antibiofilm approaches: prevention of catheter colonization," Chemistry and Biology, vol. 9, no. 8, pp. 873-880, 2002.

[146] K. Vasilev, J. Cook, and H. J. Griesser, "Antibacterial surfaces for biomedical devices," Expert Review of Medical Devices, vol. 6, no. 5, pp. 553-567, 2009.

[147] R. Kügler, O. Bouloussa, and F. Rondelez, "Evidence of a chargedensity threshold for optimum efficiency of biocidal cationic surfaces," Microbiology, vol. 151, no. 5, pp. 1341-1348, 2005.

[148] D. A. Salick, J. K. Kretsinger, D. J. Pochan, and J. P. Schneider, "Inherent antibacterial activity of a peptide-based $\beta$-hairpin hydrogel," Journal of the American Chemical Society, vol. 129, no. 47, pp. 14793-14799, 2007.

[149] D. F. Williams, "On the mechanisms of biocompatibility," Biomaterials, vol. 29, no. 20, pp. 2941-2953, 2008.

[150] J. J. Boelens, J. Dankert, J. L. Murk et al., "Biomaterialassociated persistence of Staphylococcus epidermidis in pericatheter macrophages," Journal of Infectious Diseases, vol. 181, no. 4, pp. 1337-1349, 2000.

[151] E. Taylor and T. J. Webster, "Reducing infections through nanotechnology and nanoparticles," International Journal of Nanomedicine, vol. 6, pp. 1463-1473, 2011.
[152] P. A. Suci, D. L. Berglund, L. Liepold et al., "High-density targeting of a viral multifunctional nanoplatform to a pathogenic, biofilm-forming bacterium," Chemistry and Biology, vol. 14, no. 4, pp. 387-398, 2007.

[153] G. Colon, B. C. Ward, and T. J. Webster, "Increased osteoblast and decreased Staphylococcus epidermidis functions on nanophase $\mathrm{ZnO}$ and $\mathrm{TiO}_{2}$," Journal of Biomedical Materials Research Part A, vol. 78, no. 3, pp. 595-604, 2006.

[154] N. Jones, B. Ray, K. T. Ranjit, and A. C. Manna, "Antibacterial activity of $\mathrm{ZnO}$ nanoparticle suspensions on a broad spectrum of microorganisms," FEMS Microbiology Letters, vol. 279, no. 1, pp. 71-76, 2008.

[155] S. D. Puckett, E. Taylor, T. Raimondo, and T. J. Webster, “The relationship between the nanostructure of titanium surfaces and bacterial attachment," Biomaterials, vol. 31, no. 4, pp. 706713, 2010.

[156] M. Salwiczek, Y. Qu, J. Gardiner et al., "Emerging rules for effective antimicrobial coatings," Trends in Biotechnology, vol. 32, no. 2, pp. 82-90, 2014.

[157] A. V. Singh, V. Vyas, R. Patil et al., "Quantitative characterization of the influence of the nanoscale morphology of nanostructured surfaces on bacterial adhesion and biofilm formation," PLOS ONE, vol. 6, no. 9, Article ID e25029, 2011.

[158] J. V. Loh, S. L. Percival, E. J. Woods, N. J. Williams, and C. A. Cochrane, "Silver resistance in MRSA isolated from wound and nasal sources in humans and animals," International Wound Journal, vol. 6, no. 1, pp. 32-38, 2009.

[159] D. Inbakandan, C. Kumar, L. S. Abraham, R. Kirubagaran, R. Venkatesan, and S. A. Khan, "Silver nanoparticles with anti microfouling effect: a study against marine biofilm forming bacteria," Colloids and Surfaces B: Biointerfaces, vol. 111, pp. 636643, 2013.

[160] R. K. Bera, S. M. Mandal, and C. R. Raj, "Antimicrobial activity of fluorescent Ag nanoparticles," Letters in Applied Microbiology, vol. 58, no. 6, pp. 520-526, 2014.

[161] R. Sinha, R. Karan, A. Sinha, and S. K. Khare, "Interaction and nanotoxic effect of $\mathrm{ZnO}$ and $\mathrm{Ag}$ nanoparticles on mesophilic and halophilic bacterial cells," Bioresource Technology, vol. 102, no. 2, pp. 1516-1520, 2011.

[162] M. A. Ansari, H. M. Khan, A. A. Khan, S. S. Cameotra, and M. A. Alzohairy, "Anti-biofilm efficacy of silver nanoparticles against MRSA and MRSE isolated from wounds in a tertiary care hospital," Indian Journal of Medical Microbiology, vol. 33, no. 1, pp. 101-109, 2015.

[163] K. Naik and M. Kowshik, "Anti-biofilm efficacy of low temperature processed $\mathrm{AgCl}-\mathrm{TiO}_{2}$ nanocomposite coating," Materials Science and Engineering: C, vol. 34, no. 1, pp. 62-68, 2014.

[164] V. Kostenko, J. Lyczak, K. Turner, and R. J. Martinuzzi, “Impact of silver-containing wound dressings on bacterial biofilm viability and susceptibility to antibiotics during prolonged treatment," Antimicrobial Agents and Chemotherapy, vol. 54, no. 12, pp. 5120-5131, 2010.

[165] J.-H. Lee, Y.-G. Kim, M. H. Cho, and J. Lee, "ZnO nanoparticles inhibit Pseudomonas aeruginosa biofilm formation and virulence factor production," Microbiological Research, vol. 169, no. 12, pp. 888-896, 2014.

[166] B. M. Geilich and T. J. Webster, "Reduced adhesion of Staphylococcus aureus to $\mathrm{ZnO} / \mathrm{PVC}$ nanocomposites," in Proceedings of the 39th Annual Northeast Bioengineering Conference (NEBEC '13), pp. 7-8, IEEE, Syracuse, NY, USA, April 2013.

[167] W. Zhang, E. S. McLamore, N. T. Garland, J. V. C. Leon, and M. K. Banks, "A simple method for quantifying biomass cell 
and polymer distribution in biofilms," Journal of Microbiological Methods, vol. 94, no. 3, pp. 367-374, 2013.

[168] F. Haghighi, S. Roudbar Mohammadi, P. Mohammadi, S. Hosseinkhani, and R. Shipour, "Antifungal activity of $\mathrm{TiO}_{2}$ nanoparticles and EDTA on Candida albicans biofilms," Epidemiology and Medicine, vol. 1, no. 1, pp. 33-38, 2013.

[169] Y. Ohko, Y. Nagao, K. Okano et al., "Prevention of Phormidium tenue biofilm formation by $\mathrm{TiO}_{2}$ photocatalysis," Microbes and Environments, vol. 24, no. 3, pp. 241-245, 2009.

[170] K. Naik, A. Chatterjee, H. Prakash, and M. Kowshik, "Mesoporous $\mathrm{TiO}_{2}$ nanoparticles containing Ag ion with excellent antimicrobial activity at remarkable low silver concentrations," Journal of Biomedical Nanotechnology, vol. 9, no. 4, pp. 664-673, 2013.

[171] G. Ren, D. Hu, E. W. C. Cheng, M. A. Vargas-Reus, P. Reip, and R. P. Allaker, "Characterisation of copper oxide nanoparticles for antimicrobial applications," International Journal of Antimicrobial Agents, vol. 33, no. 6, pp. 587-590, 2009.

[172] L. Esteban-Tejeda, F. Malpartida, A. Esteban-Cubillo, C. Pecharromn, and J. S. Moya, "Antibacterial and antifungal activity of a soda-lime glass containing copper nanoparticles," Nanotechnology, vol. 20, no. 50, Article ID 505701, 2009.

[173] J. P. Ruparelia, A. K. Chatterjee, S. P. Duttagupta, and S. Mukherji, "Strain specificity in antimicrobial activity of silver and copper nanoparticles," Acta Biomaterialia, vol. 4, no. 3, pp. 707-716, 2008.

[174] P. S. Murthy, V. Venugopalan, D. A. Das, S. Dhara, R. Pandiyan, and A. Tyagi, "Antibiofilm activity of nano sized $\mathrm{CuO}$," in Proceedings of the International Conference on Nanoscience, Engineering and Technology (ICONSET '11), pp. 580-583, IEEE, November 2011.

[175] M. Eshed, J. Lellouche, S. Matalon, A. Gedanken, and E. Banin, "Sonochemical coatings of $\mathrm{ZnO}$ and $\mathrm{CuO}$ nanoparticles inhibit Streptococcus mutans biofilm formation on teeth model," Langmuir, vol. 28, no. 33, pp. 12288-12295, 2012.

[176] E. N. Taylor, C. P. Toseland, T. K. Attwood, and D. R. Flower, "About novoseek," International Journal of Nanomedicine, vol. 4, pp. 145-152, 2009.

[177] M. C. Chifiriuc, A. M. Grumezescu, E. Andronescu et al., "Water dispersible magnetite nanoparticles influence the efficacy of antibiotics against planktonic and biofilm embedded Enterococcus faecalis cells," Anaerobe, vol. 22, pp. 14-19, 2013.

[178] I. Anghel, C. Limban, A. M. Grumezescu, A. G. Anghel, C. Bleotu, and M. C. Chifiriuc, "In vitro evaluation of antipathogenic surface coating nanofluid, obtained by combining $\mathrm{Fe}_{3} \mathrm{O}_{4} / \mathrm{C}_{12}$ nanostructures and 2-((4-ethylphenoxy) methyl)$\mathrm{N}$-(substituted-phenylcarbamothioyl)-benzamides," Nanoscale Research Letters, vol. 7, pp. 1-10, 2012.

[179] Q. Yu, J. Li, Y. Zhang, Y. Wang, L. Liu, and M. Li, "Inhibition of gold nanoparticles (AuNPs) on pathogenic biofilm formation and invasion to host cells," Scientific Reports, vol. 6, Article ID 26667, 2016.

[180] A. N. Brown, K. Smith, T. A. Samuels, J. Lu, S. O. Obare, and M. E. Scott, "Nanoparticles functionalized with ampicillin destroy multiple-antibiotic-resistant isolates of Pseudomonas aeruginosa and Enterobacter aerogenes and methicillin-resistant Staphylococcus aureus," Applied and Environmental Microbiology, vol. 78, no. 8, pp. 2768-2774, 2012.

[181] M. Chamundeeswari, S. S. L. Sobhana, J. P. Jacob et al., "Preparation, characterization and evaluation of a biopolymeric gold nanocomposite with antimicrobial activity," Biotechnology and Applied Biochemistry, vol. 55, no. 1, pp. 29-35, 2010.
[182] H. Mu, J. Tang, Q. Liu, C. Sun, T. Wang, and J. Duan, "Potent antibacterial nanoparticles against biofilm and intracellular bacteria," Scientific Reports, vol. 6, Article ID 18877, 2016.

[183] W.-Y. Chen, J.-Y. Lin, W.-J. Chen, L. Luo, E. Wei-Guang Diau, and Y.-C. Chen, "Functional gold nanoclusters as antimicrobial agents for antibiotic-resistant bacteria," Nanomedicine, vol. 5, no. 5, pp. 755-764, 2010.

[184] J. A. Lichter and M. F. Rubner, "Polyelectrolyte multilayers with intrinsic antimicrobial functionality: the importance of mobile polycations," Langmuir, vol. 25, no. 13, pp. 7686-7694, 2009.

[185] B. A. Nevius, Y. P. Chen, J. L. Ferry, and A. W. Decho, "Surfacefunctionalization effects on uptake of fluorescent polystyrene nanoparticles by model biofilms," Ecotoxicology, vol. 21, no. 8, pp. 2205-2213, 2012.

[186] M. A. Hillmyer, "Nanoporous materials from block copolymer precursors," in Block Copolymers II, pp. 137-181, Springer, Berlin, Germany, 2005.

[187] W. S. Cheow, M. W. Chang, and K. Hadinoto, "Antibacterial efficacy of inhalable antibiotic-encapsulated biodegradable polymeric nanoparticles against E. coli biofilm cells," Journal of Biomedical Nanotechnology, vol. 6, no. 4, pp. 391-403, 2010.

[188] X. Li, P. Li, R. Saravanan et al., "Antimicrobial functionalization of silicone surfaces with engineered short peptides having broad spectrum antimicrobial and salt-resistant properties," Acta Biomaterialia, vol. 10, no. 1, pp. 258-266, 2014.

[189] S. B. Goodman, Z. Yao, M. Keeney, and F. Yang, "The future of biologic coatings for orthopaedic implants," Biomaterials, vol. 34, no. 13, pp. 3174-3183, 2013.

[190] P. J. Nowatzki, R. R. Koepsel, P. Stoodley et al., "Salicylic acid-releasing polyurethane acrylate polymers as anti-biofilm urological catheter coatings," Acta Biomaterialia, vol. 8, no. 5, pp. 1869-1880, 2012.

[191] L. G. Harris, S. Tosatti, M. Wieland, M. Textor, and R. G. Richards, "Staphylococcus aureus adhesion to titanium oxide surfaces coated with non-functionalized and peptide-functionalized poly(L-lysine)-grafted-poly(ethylene glycol) copolymers," Biomaterials, vol. 25, no. 18, pp. 4135-4148, 2004.

[192] P. Kingshott, J. Wei, D. Bagge-Ravn, N. Gadegaard, and L. Gram, "Covalent attachment of poly (ethylene glycol) to surfaces, critical for reducing bacterial adhesion," Langmuir, vol. 19, no. 17, pp. 6912-6921, 2003.

[193] K. Bruellhoff, J. Fiedler, M. Möller, J. Groll, and R. E. Brenner, "Surface coating strategies to prevent biofilm formation on implant surfaces," The International Journal of Artificial Organs, vol. 33, no. 9, pp. 646-653, 2010.

[194] F. Zhang, Z. Zhang, X. Zhu, E.-T. Kang, and K.-G. Neoh, "Silk-functionalized titanium surfaces for enhancing osteoblast functions and reducing bacterial adhesion," Biomaterials, vol. 29, no. 36, pp. 4751-4759, 2008.

[195] E. M. Hetrick, J. H. Shin, N. A. Stasko et al., "Bactericidal efficacy of nitric oxide-releasing silica nanoparticles," ACS Nano, vol. 2, no. 2, pp. 235-246, 2008.

[196] L. R. Martinez, G. Han, M. Chacko et al., "Antimicrobial and healing efficacy of sustained release nitric oxide nanoparticles against Staphylococcus aureus skin infection," Journal of Investigative Dermatology, vol. 129, no. 10, pp. 2463-2469, 2009.

[197] M. R. Mihu, U. Sandkovsky, G. Han, J. M. Friedman, J. D. Nosanchuk, and L. R. Martinez, "The use of nitric oxide releasing nanoparticles as a treatment against Acinetobacter baumannii in wound infections," Virulence, vol. 1, no. 2, pp. 6267, 2010. 
[198] C. Macherla, D. A. Sanchez, M. S. Ahmadi et al., "Nitric oxide releasing nanoparticles for treatment of Candida albicans burn infections," Frontiers in Microbiology, vol. 3, article 193, 2012.

[199] D. Depan and R. D. K. Misra, "On the determining role of network structure titania in silicone against bacterial colonization: mechanism and disruption of biofilm," Materials Science and Engineering: C, vol. 34, no. 1, pp. 221-228, 2014.

[200] H. Ma, E. T. Darmawan, M. Zhang, L. Zhang, and J. D. Bryers, "Development of a poly (ether urethane) system for the controlled release of two novel anti-biofilm agents based on gallium or zinc and its efficacy to prevent bacterial biofilm formation," Journal of Controlled Release, vol. 172, no. 3, pp. 1035-1044, 2013.

[201] K. Ramalingam, N. C. Frohlich, and V. A. Lee, "Effect of nanoemulsion on dental unit waterline biofilm," Journal of Dental Sciences, vol. 8, no. 3, pp. 333-336, 2013.

[202] J. Janiszewska, J. Swieton, A. W. Lipkowski, and Z. UrbanczykLipkowska, "Low molecular mass peptide dendrimers that express antimicrobial properties," Bioorganic and Medicinal Chemistry Letters, vol. 13, no. 21, pp. 3711-3713, 2003.

[203] E. M. V. Johansson, S. A. Crusz, E. Kolomiets et al., "Inhibition and dispersion of Pseudomonas aeruginosa biofilms by glycopeptide dendrimers targeting the fucose-specific lectin LecB," Chemistry and Biology, vol. 15, no. 12, pp. 1249-1257, 2008.

[204] A. Gharbi, V. Humblot, F. Turpin, C.-M. Pradier, C. Imbert, and J.-M. Berjeaud, "Elaboration of antibiofilm surfaces functionalized with antifungal-cyclodextrin inclusion complexes," FEMS Immunology and Medical Microbiology, vol. 65, no. 2, pp. 257269, 2012.

[205] C. A. B. Nava-Ortiz, G. Burillo, A. Concheiro et al., "Cyclodextrin-functionalized biomaterials loaded with miconazole prevent Candida albicans biofilm formation in vitro," Acta Biomaterialia, vol. 6, no. 4, pp. 1398-1404, 2010.

[206] B. Blanco-Fernandez, M. Lopez-Viota, A. Concheiro, and C. Alvarez-Lorenzo, "Synergistic performance of cyclodextrinagar hydrogels for ciprofloxacin delivery and antimicrobial effect," Carbohydrate Polymers, vol. 85, no. 4, pp. 765-774, 2011.

[207] Z. Drulis-Kawa, A. Dorotkiewicz-Jach, J. Gubernator, G. Gula, T. Bocer, and W. Doroszkiewicz, "The interaction between Pseudomonas aeruginosa cells and cationic PC: Chol: DOTAP liposomal vesicles versus outer-membrane structure and envelope properties of bacterial cell," International Journal of Pharmaceutics, vol. 367, no. 1, pp. 211-219, 2009.

[208] M. Alipour, M. Halwani, A. Omri, and Z. E. Suntres, "Antimicrobial effectiveness of liposomal polymyxin B against resistant Gram-negative bacterial strains," International Journal of Pharmaceutics, vol. 355, no. 1-2, pp. 293-298, 2008.

[209] M. Alhariri and A. Omri, "Efficacy of liposomal bismuthethanedithiol-loaded tobramycin after intratracheal administration in rats with pulmonary Pseudomonas aeruginosa infection," Antimicrobial Agents and Chemotherapy, vol. 57, no. 1, pp. 569-578, 2013.

[210] X. F. Wang, S. L. Zhang, L. Y. Zhu et al., "Enhancement of antibacterial activity of tilmicosin against Staphylococcus aureus by solid lipid nanoparticles in vitro and in vivo," The Veterinary Journal, vol. 191, no. 1, pp. 115-120, 2012.

[211] A. Garg and S. Singh, "Enhancement in antifungal activity of eugenol in immunosuppressed rats through lipid nanocarriers," Colloids and Surfaces B: Biointerfaces, vol. 87, no. 2, pp. 280-288, 2011.

[212] I. S. I. Al-Adham, N. D. Al-Hmoud, E. Khalil, M. Kierans, and P. J. Collier, "Microemulsions are highly effective anti-biofilm agents," Letters in Applied Microbiology, vol. 36, no. 2, pp. 97$100,2003$.

[213] I. S. I. Al-Adham, H. Ashour, E. Al-Kaissi, E. Khalil, M. Kierans, and P. J. Collier, "Studies on the kinetics of killing and the proposed mechanism of action of microemulsions against fungi," International Journal of Pharmaceutics, vol. 454, no. 1, pp. 226-232, 2013.

[214] M.-S. Wong, C.-W. Chen, C.-C. Hsieh, S.-C. Hung, D.-S. Sun, and H.-H. Chang, "Antibacterial property of Ag nanoparticleimpregnated N-doped titania films under visible light," Scientific Reports, vol. 5, Article ID 11978, 2015.

[215] J.-H. Lee, Y.-G. Kim, K. Lee, S.-C. Kim, and J. Lee, "Temperature-dependent control of Staphylococcus aureus biofilms and virulence by thermoresponsive oligo ( $\mathrm{N}$ vinylcaprolactam)," Biotechnology and Bioengineering, vol. 112, no. 4, pp. 716-724, 2015.

[216] V. P. Zharov, K. E. Mercer, E. N. Galitovskaya, and M. S. Smeltzer, "Photothermal nanotherapeutics and nanodiagnostics for selective killing of bacteria targeted with gold nanoparticles," Biophysical Journal, vol. 90, no. 2, pp. 619-627, 2006.

[217] D. Maity, P. Chandrasekharan, C.-T. Yang et al., "Facile synthesis of water-stable magnetite nanoparticles for clinical MRI and magnetic hyperthermia applications," Nanomedicine, vol. 5, no. 10, pp. 1571-1584, 2010.

[218] M. Ramasamy, S. Kim, S. S. Lee, and D. K. Yi, "Recyclable photothermal nano-aggregates of magnetic nanoparticle conjugated gold nanorods for effective pathogenic bacteria lysis," Journal of Nanoscience and Nanotechnology, vol. 16, no. 1, pp. 555-561, 2016.

[219] M.-C. Wu, A. R. Deokar, J.-H. Liao, P.-Y. Shih, and Y.-C. Ling, "Graphene-based photothermal agent for rapid and effective killing of bacteria," ACS Nano, vol. 7, no. 2, pp. 1281-1290, 2013.

[220] Y. Zhu, M. Ramasamy, and D. K. Yi, "Antibacterial activity of ordered gold nanorod arrays," ACS Applied Materials and Interfaces, vol. 6, no. 17, pp. 15078-15085, 2014.

[221] S. S. Lucky, K. C. Soo, and Y. Zhang, "Nanoparticles in photodynamic therapy," Chemical Reviews, vol. 115, no. 4, pp. 1990-2042, 2015.

[222] S. Ferro, F. Ricchelli, G. Mancini, G. Tognon, and G. Jori, "Inactivation of methicillin-resistant Staphylococcus aureus (MRSA) by liposome-delivered photosensitising agents," Journal of Photochemistry and Photobiology B: Biology, vol. 83, no. 2, pp. 98104, 2006.

[223] S. Khan, F. Alam, A. Azam, and A. U. Khan, "Gold nanoparticles enhance methylene blue-induced photodynamic therapy: a novel therapeutic approach to inhibit Candida albicans biofilm," International Journal of Nanomedicine, vol. 7, pp. 3245-3257, 2012.

[224] A. Shrestha and A. Kishen, "Antibiofilm efficacy of photosensitizer-functionalized bioactive nanoparticles on multispecies biofilm," Journal of Endodontics, vol. 40, no. 10, pp. 1604-1610, 2014.

[225] H. Park, H.-J. Park, J. A. Kim et al., "Inactivation of Pseudomonas aeruginosa PA01 biofilms by hyperthermia using superparamagnetic nanoparticles," Journal of Microbiological Methods, vol. 84, no. 1, pp. 41-45, 2011.

[226] M.-H. Kim, I. Yamayoshi, S. Mathew, H. Lin, J. Nayfach, and S. I. Simon, "Magnetic nanoparticle targeted hyperthermia of cutaneous Staphylococcus aureus infection," Annals of Biomedical Engineering, vol. 41, no. 3, pp. 598-609, 2013. 
[227] J. R. Morones, J. L. Elechiguerra, A. Camacho et al., "The bactericidal effect of silver nanoparticles," Nanotechnology, vol. 16, no. 10, pp. 2346-2353, 2005.

[228] S. Pal, Y. K. Tak, and J. M. Song, "Does the antibacterial activity of silver nanoparticles depend on the shape of the nanoparticle? A study of the gram-negative bacterium Escherichia coli," Applied and Environmental Microbiology, vol. 73, no. 6, pp. 17121720, 2007.

[229] A. M. El Badawy, R. G. Silva, B. Morris, K. G. Scheckel, M. T. Suidan, and T. M. Tolaymat, "Surface charge-dependent toxicity of silver nanoparticles," Environmental Science and Technology, vol. 45, no. 1, pp. 283-287, 2011.

[230] M. J. Hajipour, K. M. Fromm, A. Akbar Ashkarran et al., "Antibacterial properties of nanoparticles," Trends in Biotechnology, vol. 30, no. 10, pp. 499-511, 2012.

[231] J. A. Lemire, J. J. Harrison, and R. J. Turner, "Antimicrobial activity of metals: mechanisms, molecular targets and applications," Nature Reviews Microbiology, vol. 11, no. 6, pp. 371-384, 2013.

[232] R. Y. Pelgrift and A. J. Friedman, "Nanotechnology as a therapeutic tool to combat microbial resistance," Advanced Drug Delivery Reviews, vol. 65, no. 13-14, pp. 1803-1815, 2013.

[233] S. L. Warnes, V. Caves, and C. W. Keevil, "Mechanism of copper surface toxicity in Escherichia coli O157:H7 and Salmonella involves immediate membrane depolarization followed by slower rate of DNA destruction which differs from that observed for Gram-positive bacteria," Environmental Microbiology, vol. 14, no. 7, pp. 1730-1743, 2012.

[234] H. Yun, J. D. Kim, H. C. Choi, and C. W. Lee, "Antibacterial activity of CNT-Ag and GO-Ag nanocomposites against gramnegative and gram-positive bacteria," Bulletin of the Korean Chemical Society, vol. 34, no. 11, pp. 3261-3264, 2013.

[235] G. A. Sotiriou and S. E. Pratsinis, "Antibacterial activity of nanosilver ions and particles," Environmental Science and Technology, vol. 44, no. 14, pp. 5649-5654, 2010.

[236] R. Hong, T. Y. Kang, C. A. Michels, and N. Gadura, "Membrane lipid peroxidation in copper alloy-mediated contact killing of Escherichia coli," Applied and Environmental Microbiology, vol. 78, no. 6, pp. 1776-1784, 2012.

[237] G. Subbiahdoss, S. Sharifi, D. W. Grijpma et al., "Magnetic targeting of surface-modified superparamagnetic iron oxide nanoparticles yields antibacterial efficacy against biofilms of gentamicin-resistant staphylococci," Acta Biomaterialia, vol. 8, no. 6, pp. 2047-2055, 2012.

[238] C. E. Santo, E. W. Lam, C. G. Elowsky et al., "Bacterial killing by dry metallic copper surfaces," Applied and Environmental Microbiology, vol. 77, no. 3, pp. 794-802, 2011.

[239] I. Sondi and B. Salopek-Sondi, "Silver nanoparticles as antimicrobial agent: a case study on E. coli as a model for Gramnegative bacteria," Journal of Colloid and Interface Science, vol. 275, no. 1, pp. 177-182, 2004.

[240] A. Friedman, K. Blecher, D. Sanchez et al., "Susceptibility of Gram-positive and-negative bacteria to novel nitric oxidereleasing nanoparticle technology," Virulence, vol. 2, no. 3, pp. 217-221, 2011.

[241] S. Egger, R. P. Lehmann, M. J. Height, M. J. Loessner, and M. Schuppler, "Antimicrobial properties of a novel silver-silica nanocomposite material," Applied and Environmental Microbiology, vol. 75, no. 9, pp. 2973-2976, 2009.

[242] I. Iavicoli, L. Fontana, V. Leso, and A. Bergamaschi, “The effects of nanomaterials as endocrine disruptors," International Journal of Molecular Sciences, vol. 14, no. 8, pp. 16732-16801, 2013. 

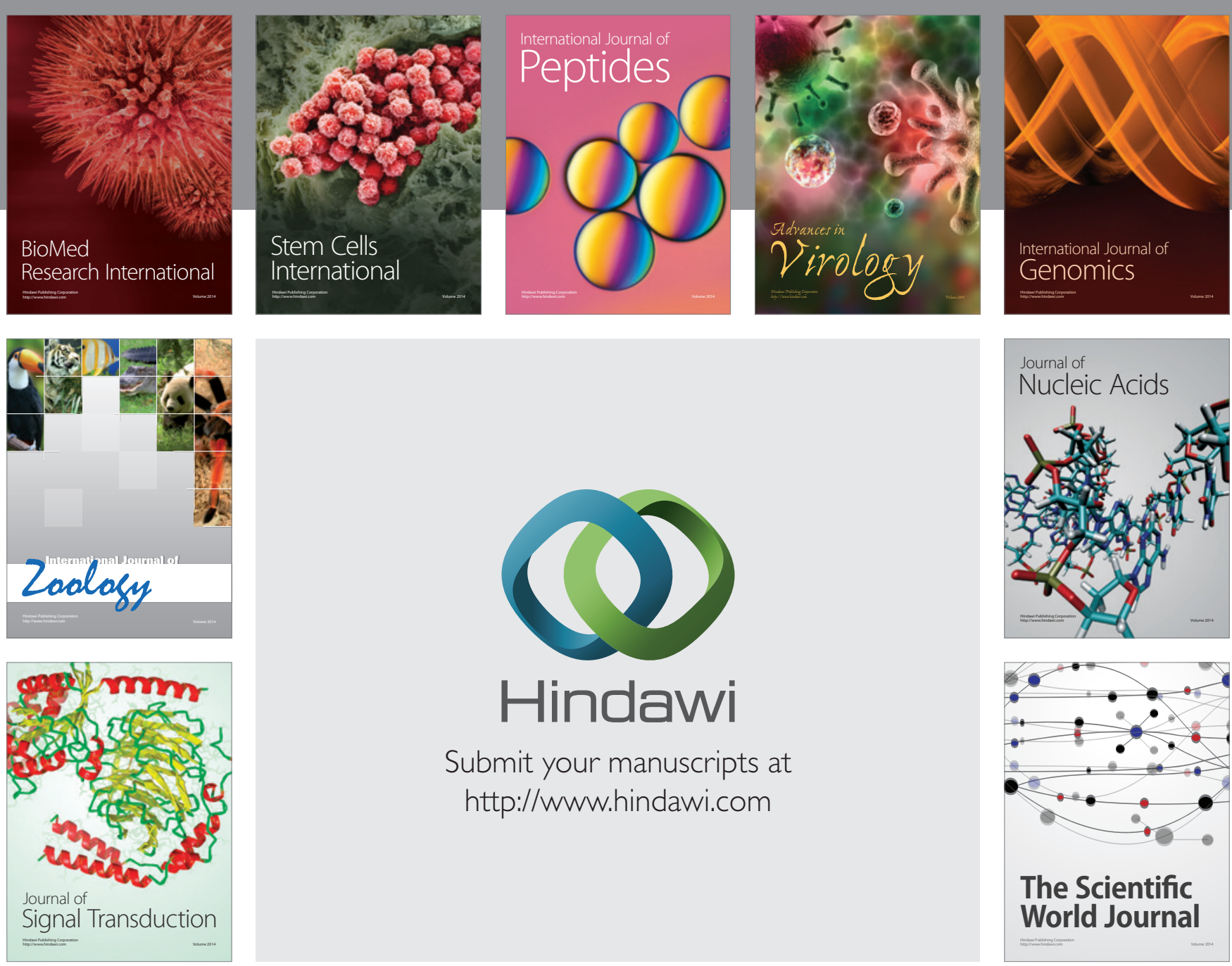

Submit your manuscripts at

http://www.hindawi.com
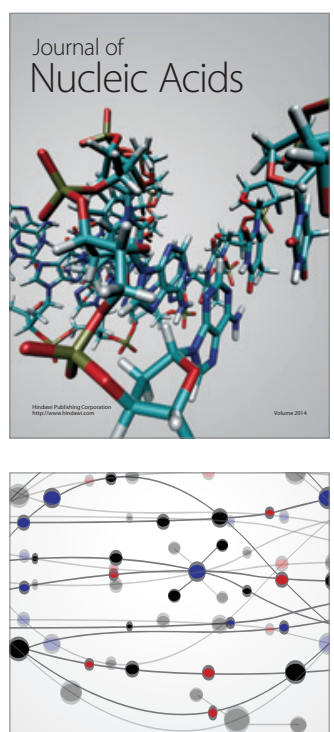

The Scientific World Journal
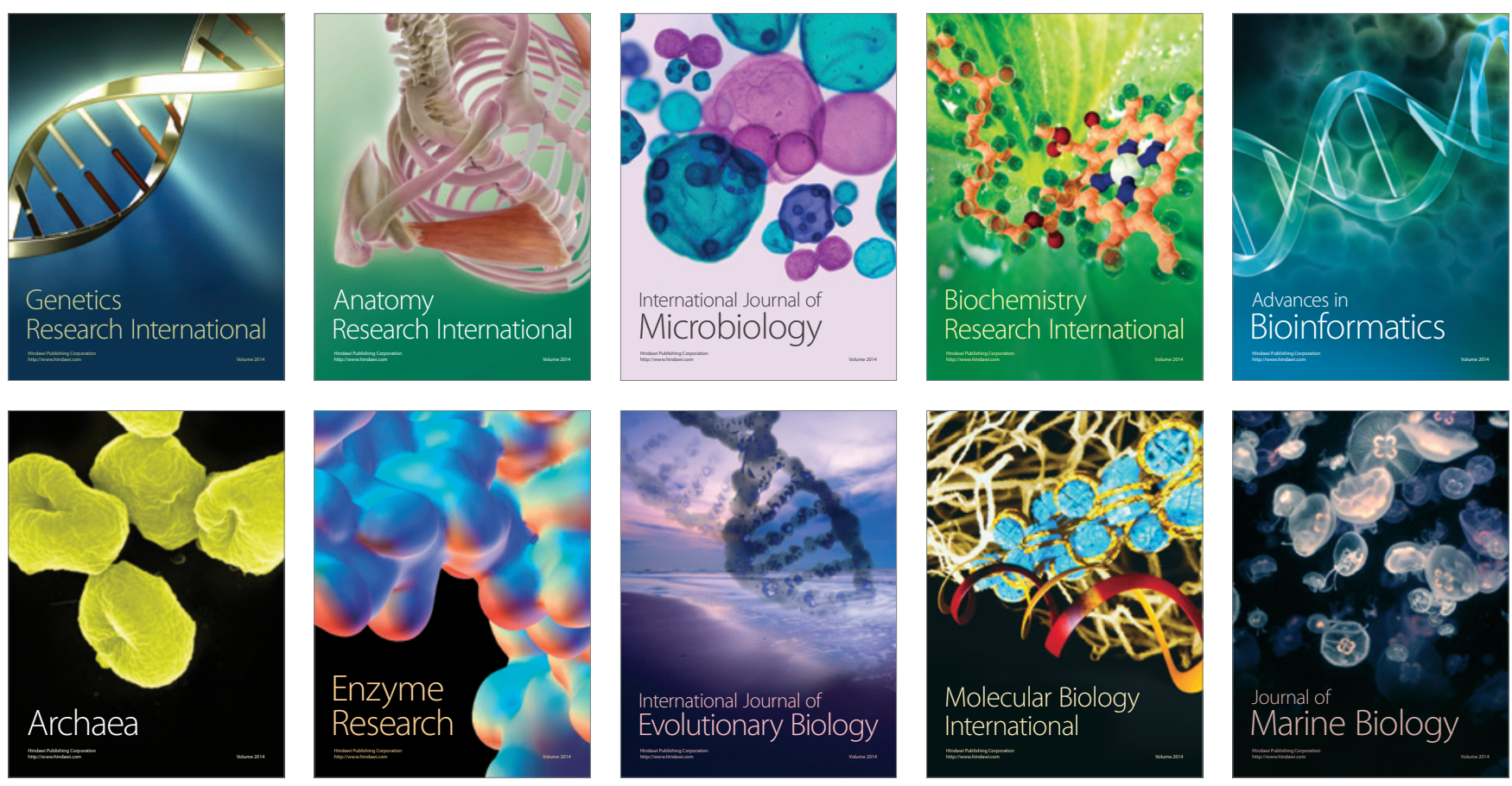